Article

\title{
Dynamics of Mesozooplankton Assemblage in Relation to Environmental Factors in the Maryland Coastal Bays
}

\section{Efeturi U. Oghenekaro and Paulinus Chigbu *}

NSF CREST-Center for the Integrated Study of Coastal Ecosystem Processes and Dynamics in the Mid-Atlantic Region, and NOAA Living Marine Resources Cooperative Science Center, Department of Natural Sciences, University of Maryland Eastern Shore, Princess Anne, MD 21853, USA; euoghenekaro@umes.edu

* Correspondence: pchigbu@umes.edu; Tel.: +14-10-621-3034

Received: 16 August 2019; Accepted: 4 October 2019; Published: 14 October 2019

\begin{abstract}
The mesozooplankton composition and dynamics in coastal lagoons of Maryland, mid-Atlantic region, USA have received little scientific attention despite the fact that the lagoons have undergone changes in water quality in the past two decades. We compared mesozooplankton abundance and community structure among sites and seasons, and between 2012, a year of higher than average salinity (33.4), and 2013 with lower than average salinity (26.6). It was observed that the composition, diversity, and abundance of mesozooplankton in 2012 differed from those of 2013. Barnacle nauplii were abundant in 2012 contributing $31 \%$ of the non-copepod mesozooplankton abundance, whereas hydromedusae were more dominant in 2013 and contributed up to $83 \%$ of non-copepod zooplankton abundance. Gastropod veliger larvae were more abundant in 2013 than in 2012 while larvae of bivalves, polychaetes, and decapods, in addition to cladocerans and ostracods had higher abundances in 2012. The abundance and diversity of mesozooplankton were explained by variations in environmental factors particularly salinity, and by the abundance of predators such as bay anchovy (Anchoa mitchelli). Diversity was higher in spring and summer 2012 (dry year) than in 2013 (wet year). The reduction of salinity in fall 2012, due to high freshwater discharge associated with Hurricane Sandy, was accompanied by a decrease in mesozooplankton diversity. Spatially, diversity was higher at sites with high salinity near the Ocean City Inlet than at sites near the mouth of tributaries with lower salinity, higher nutrient levels and higher phytoplankton biomass. Perhaps, the relatively low salinity and high temperature in 2013 resulted in an increase in the abundance of hydromedusae, which through predation contributed to the reduction in the abundance of bivalve larvae and other taxa.
\end{abstract}

Keywords: mesozooplankton; salinity; abundance; distribution; diversity; Maryland Coastal Bays

\section{Introduction}

Planktonic organisms ranging in size $0.2-20 \mathrm{~mm}$ are referred to as mesozooplankton [1]; examples are copepods, decapod zoea, rotifers, gastropod veliger, barnacle nauplii, larvaceans, cladocerans and bivalve larvae. Mesozooplankton are major grazers of primary producers, and important predators of microzooplankton, including ciliates, thereby acting as a pathway for transfer of materials and energy from microbial food web to higher trophic levels [2,3]. Copepods are the most abundant of, and contribute the most biomass to, the mesozooplankton group in marine and estuarine zooplankton [4].

Although non-copepods do not constitute the bulk of mesozooplankton in United States mid-Atlantic estuaries, they occasionally become abundant [5-7] and play an important role in 
the diet of zooplanktivores [8,9]. Mesozooplankton composition, abundance and diversity in estuaries and coastal lagoons vary seasonally, spatially and between years in response to abiotic and biotic factors [10-16], and have been well documented in large river-dominated estuaries of the mid-Atlantic such as the Chesapeake Bay $[12,17]$ and Delaware Bay $[18,19]$. Nevertheless, we know little about mesozooplankton composition and dynamics in Maryland Coastal Bays (MCBs), which are poorly flushed, eutrophic, largely polyhaline lagoonal systems that receive relatively small amount of freshwater directly from tributary rivers and creeks. Because of differences in the hydrography, the composition, abundance and distribution of mesozooplankton in MCBs may be different than those of river-dominated estuaries, and are expected to vary between years due to variations in climatic factors.

The coastal bays support commercially and recreationally important species of shellfish such as blue crabs (Callinectes sapidus) and hard clams (Mercenaria mercenaria) which rely on the successful recruitment of their meroplanktonic larvae to sustain the adult populations. The blue crab is the most abundant shellfish in the MCBs and requires high salinity waters for spawning and larval development $[20,21]$. In the Chesapeake Bay, C. sapidus spawn near the mouth of the estuary, or in the nearby coastal ocean $[6,22]$. The larvae (zoeae) are then transported into adjacent coastal waters on the continental shelf [23-25] where they develop through seven or eight zoeal stages before subsequently returning as post-larvae and juveniles to the estuary [25], while the adults remain resident in the system. Due to the high salinity ( $>26$ ) levels in a large portion of the MCBs, it has been hypothesized that resident adult populations of the $C$. sapidus spawn in the high saline waters of the coastal bays and the larvae complete their development within the Bays [26]. In the 2014 updated Coastal Bays Blue Crab Fishery Management Plan Implementation document, the need for studies to determine the "level of localized reproduction and entrapment of larvae" of blue crabs in the MCBs was emphasized.

Furthermore, salinity in the MCBs increased after the opening of the Ocean City Inlet in 1933, which favored the development of hard clams (M. mercenaria) and, by the 1960s, the fishery superseded the commercial landings and value of oysters in the bay [27]. The population of hard clams is currently dominated by large and older adults; the recruitment is low and intermittent except in areas close to the Ocean City Inlet, and densities are lower than historical levels [27] although increasing. Efforts to restore the population including stoppage of the hydraulic clam dredging activities have not resulted in significant increases in clam density, the cause of which is unknown, although intense predation by species such as blue crab, and the frequent occurrence of brown tide, Aureococcus anophagefferens, blooms that negatively impact bivalve larvae have been speculated to be the cause [27]. Information on the distribution and abundance of bivalve larvae, and the environmental factors influencing their abundance would be useful for designing effective management strategies to enhance bivalve populations in the MCBs.

Within the embayments in the MCBs, nutrient levels, phytoplankton biomass and fish abundance vary spatially, seasonally and inter-annually [28-30], which in addition to variations in the abundance of gelatinous zooplankton predators can influence the distribution and abundance of mesozooplankton. For example, mortality of bivalve larvae due to predation by gelatinous zooplankton can potentially slow recovery of hard clams despite the implementation of effective management plans [31,32].

The objectives of the study were:

1. To compare mesozooplankton, particularly non-copepod taxa, abundance and community structure among the MCBs embayments;

2. To determine seasonal patterns in mesozooplankton abundance and community structure;

3. To compare mesozooplankton composition, abundance and diversity between relatively dry (2012) and wet (2013) years;

4. To assess the relationships between mesozooplankton taxa abundance and abiotic and biotic factors; and

5. To use information on decapod larval occurrence to determine whether blue crabs spawn within the MCBs. 
The study addressed the following questions: Are mesozooplankton abundance and diversity higher at sites closer to the Ocean City Inlet with higher salinity, than at sites farther from the Inlet with lower salinity? Are mesozooplankton abundance and diversity higher in spring and summer 2012, a year with relatively higher salinity and lower temperature, than in 2013 when salinity was lower, and temperature higher? Do blue crabs spawn within the MCBs?

\section{Materials and Methods}

\subsection{Study Area}

The MCBs located in the Mid-Atlantic region on the east coast of the United States is separated from the Atlantic Ocean by barrier islands. This lagoonal system consists of five embayments (Figure 1) that are well mixed mostly by wave and tidal actions that facilitate the exchange of water and materials between the MCBs and the nearby coastal ocean $[29,33]$. The system, however, is poorly flushed, has low freshwater input from groundwater, rivers and tributaries, and therefore high salinity that is close to that of the ocean except in upstream areas of rivers and creeks $[28,29]$. The MCBs are relatively shallow (average depth about $1.2 \mathrm{~m}$ ) with a maximum depth of $9.3 \mathrm{~m}$ at the Ocean City Inlet [29]. Some characteristics of the northern bays watershed include low forest covers, non-point sources of pollution, dead-end canals, high stream nitrate, and nutrients from agricultural activities and development [34]. Increased nutrient input has resulted in eutrophic conditions in the northern bays and tributaries, although a similar condition exists in the Newport Bay located in the southern MCBs.

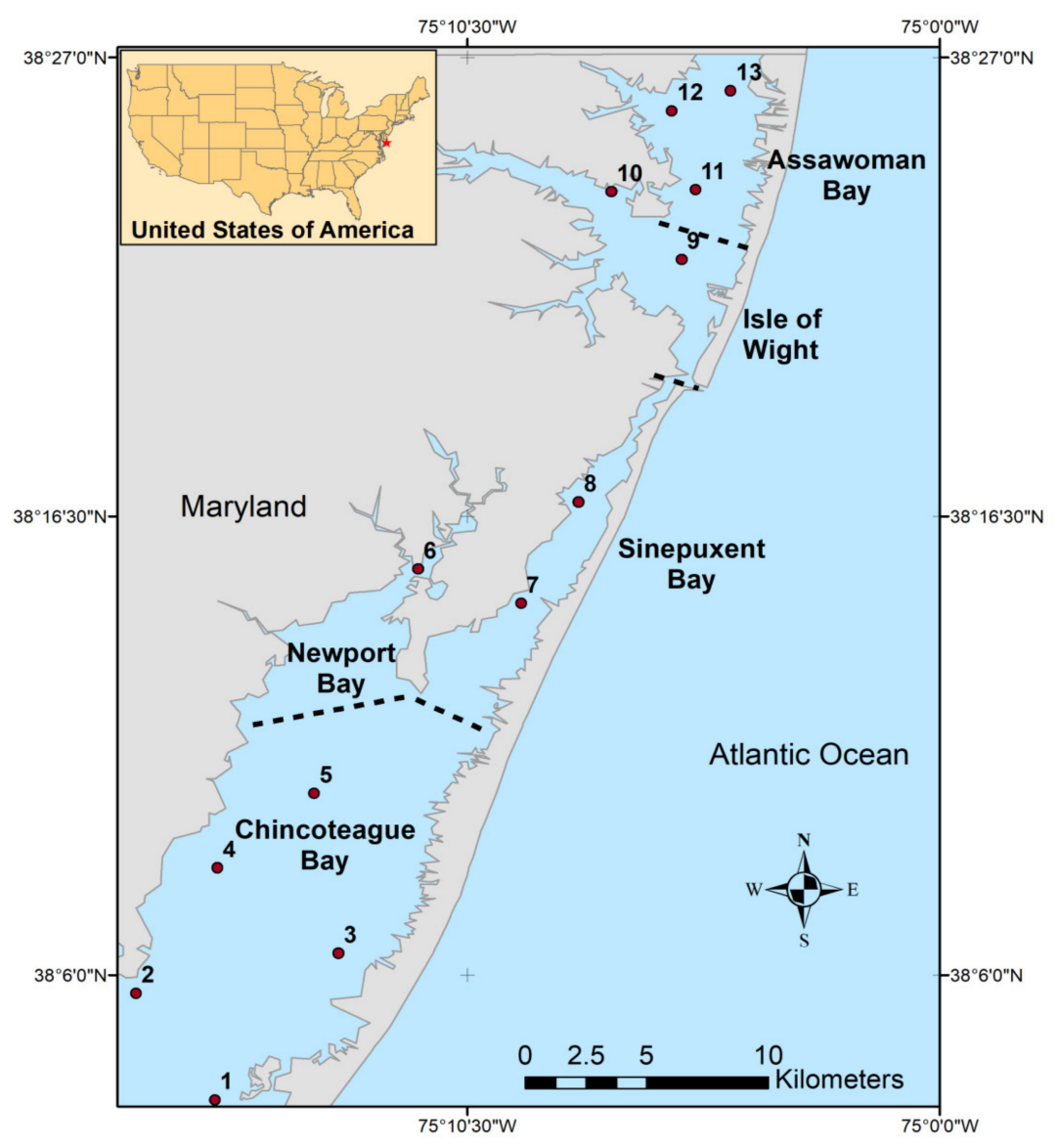

Figure 1. Map of the study area showing sampling locations within the Maryland Coastal Bays. 


\subsection{Sample Collection}

Water quality parameters such as temperature, salinity, dissolved oxygen (DO) concentration, and $\mathrm{pH}$ were measured in situ using YSI 6600 sonde. Zooplankton samples were collected monthly from February 2012 to December 2013 from 13 sites (Figure 1). Sites 1-5 are located in Chincoteague Bay (CB), Site 6 in Newport Bay (NB), Sites 7 and 8 in Sinepuxent Bay (SB), Site 9 in Isle of Wight Bay (IWB), Site 10 at the mouth of St. Martin River (SMR) and Sites 11-13 in Assawoman Bay (AB). Zooplankton sampling was conducted using a plankton net, with $60-\mathrm{cm}$ diameter mouth opening, 240-cm-long conical section, a mesh size of $200 \mu \mathrm{m}$, and a cod-end made of PVC with a volume of $1000 \mathrm{~mL}$ and diameter of $11 \mathrm{~cm}$. Because of the shallow nature of the lagoons (average depth $<2 \mathrm{~m}$ ), the net was towed horizontally in the upper meter of the water column similar to how zooplankton samples were collected in the shallow Barnegat Bay, NJ [35]. Sampling was for a duration of 2 min. The mouth opening of the net was equipped with a General Oceanic flow meter (Model 2030R) attached to the frame to measure the volume of water filtered by the net. Zooplankton samples were preserved in $5 \%$ buffered formalin solution immediately after collection. Biovolumes of gelatinous zooplankton (Mnemiopsis leidyi) were determined with a measuring cylinder.

Preserved plankton samples were processed in the lab using a dissecting microscope. A Folsom splitter was used to split samples when necessary. Samples were diluted to a known volume, and a minimum of $5 \mathrm{~mL}$ subsample was extracted with a Stemple pipette and 200-500 zooplankton individuals were counted. Cladocerans and crab zoeae were identified to species level when possible using a compound microscope and by reference to various publications $[1,36,37]$. Data on bay anchovy (Anchoa mitchelli) catch per unit effort (CPUE) were obtained from the Maryland Department of Natural Resources (MD DNR). Water samples for analyses of chlorophyll $a$ and 19'-Butanoyloxy-Fucoxanthin (But-fuco), a diagnostic pigment for pelagophytes such as the Brown tide, Aureococcus anophagefferens, were collected from $0.5 \mathrm{~m}$ below the surface using a peristaltic pump, and placed in 2-L acid-rinsed polyethylene amber bottles. The samples were kept in ice until arrival at the lab. Water samples were then filtered using a Whatman GF/F $47 \mathrm{~mm}$ filter (GE Healthcare, Fisher Scientific, Hanover Park, IL, USA) and a vacuum pump for 1-4 min. A minimum of $1 \mathrm{~L}$ by volume of water was filtered except in situations when the filter was clogged. Chlorophyll $a$ and 19'-Butanoyloxy-Fucoxanthin (But-fuco) concentrations were determined, as part of the integrated monitoring of the MCBs, using a High Performance Liquid Chromatography [38]. Freshwater discharge data for Birch branch at Showell, Maryland, USA were downloaded from the United States Geological Survey (USGS) website (http://waterdata.usgs.gov/nwis/monthly).

\subsection{Data Analyses}

The Mann-Whitney U test was used to compare mean abundance of mesozooplankton between years for each season. One-way ANOVA was used to compare differences in mean abundance of mesozooplankton among sites and embayments after $\log (x+1)$ transformation of data. The relationships between non-copepod taxa distribution and environmental factors were examined by canonical correspondence analysis (CCA), using CANOCO version 4.5 (Microcomputer Power, Ithaca, New York, USA.) [39]. Non-copepod mesozooplankton abundance was $\log (x+1)$ transformed; rare species were down-weighted when necessary and environmental data were standardized. Non-copepod mesozooplankton abundance matrices included only taxa that appeared in $>10 \%$ of the sampling sites, representing $>1 \%$ in 2012 and $>0.1 \%$ in 2013 of the non-copepod community. Shannon diversity index [40] was computed using PRIMER 6 (PRIMER-e, Auckland, North Island, New Zealand. [41]. Spearman's rank correlation was applied to identify the environmental factors (water quality variables and biota) that were associated with diversity. 


\section{Results}

\subsection{Environmental Factors}

Mean monthly water temperature in 2012 varied from $5^{\circ} \mathrm{C}$ in February to $25^{\circ} \mathrm{C}$ in July and then decreased to about $5^{\circ} \mathrm{C}$ in December (Figure 2a). In 2013, mean temperature was $30.7^{\circ} \mathrm{C}$ in July and $7^{\circ} \mathrm{C}$ in December. Water temperature was on average lower in 2012 than in 2013. Lower water temperatures were observed at sites close to the inlets, while St. Martin River had the highest mean water temperature (Table 1).
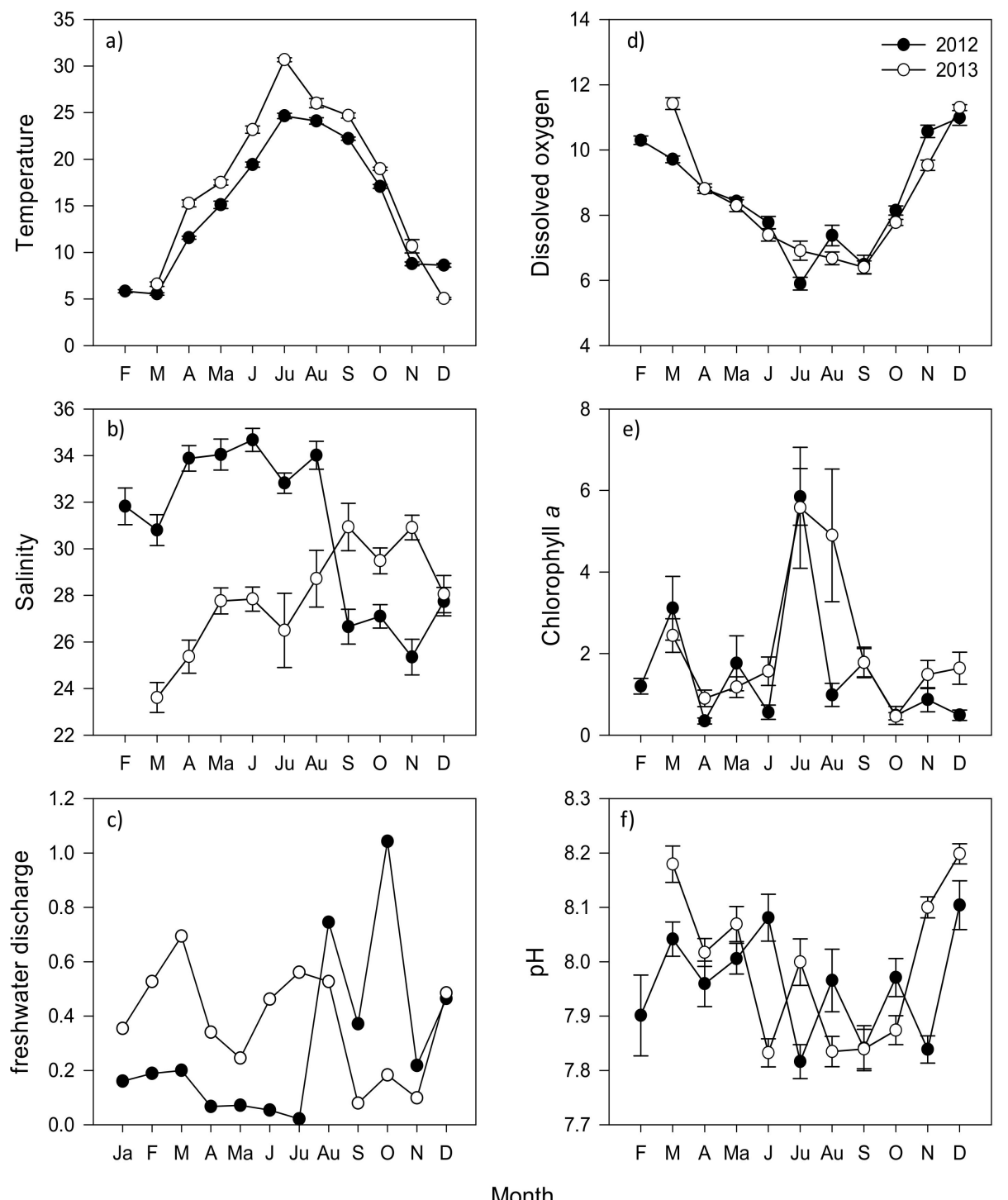

Figure 2. Seasonal patterns of environmental variables expressed as mean values \pm SE: (a) Temperature $\left({ }^{\circ} \mathrm{C}\right)$; (b) salinity; (c) Freshwater discharge $\left(\mathrm{m}^{3} \mathrm{~s}^{-1}\right)$; (d) dissolved oxygen $\left(\mathrm{mg} \mathrm{L}^{-1}\right)$; (e) Chlorophyll- $a$ $\left(\mu \mathrm{g} \mathrm{L}^{-1}\right)$; and (f) $\mathrm{pH}$.

Mean monthly salinity was higher in 2012 (33.4) than in 2013 (26.6) during the period of March to August, but the reverse occurred from September to November (Figure 2b). This salinity pattern reflected the pattern of freshwater discharge by Birch Branch at Showell, MD (Figure 2c). From January to July, Birch Branch mean discharge was higher in $2013\left(0.45 \mathrm{~m}^{3} \mathrm{~s}^{-1}\right)$ than in $2012\left(0.11 \mathrm{~m}^{3} \mathrm{~s}^{-1}\right)$, and the reverse was the case from August to November (Figure 2c). Discharge was highest in October 2012, the month that Hurricane Sandy occurred in the area. Mean monthly salinity was between 23.6 and 
34.7. Newport Bay had the lowest mean salinity level and Sinepuxent Bay had the highest salinity (Table 1). Salinity was also lower at sites in St. Martin River and Assawoman Bay relative to sites in Chincoteague and Isle of Wight Bays.

Monthly dissolved oxygen (DO) levels on the average were high in fall and winter, but relatively lower in spring and summer, although dissolved oxygen levels were $>4.6 \mathrm{mg} \mathrm{L}^{-1}$ at all sites throughout the duration of this study (Figure 2d). The lowest DO level was recorded in July (4.6 $\left.\mathrm{mg} \mathrm{L}^{-1}\right)$, and the highest in March $\left(12.7 \mathrm{mg} \mathrm{L}^{-1}\right)$.

The seasonal patterns of chlorophyll $a$ concentrations are similar in 2012 and 2013. Monthly levels of chlorophyll $a$ averaged between 0.2 and $3.4 \mu \mathrm{g} \mathrm{L}^{-1}$ (Figure 2e). Chlorophyll $a$ levels were relatively high in winter but decreased in spring, particularly in April. Chlorophyll a peaked in summer (July) in both years. Site 6 (Newport Bay) had the highest mean level of chlorophyll $a$ in the MCBs during this study (Table 1). Monthly mean $\mathrm{pH}$ levels in the MCBs ranged from 7.8 to 8.2 and did not vary much within the system (Figure 2f).

Table 1. Mean physico-chemical and biotic factors measured at sampling stations within embayments of the Maryland Coastal Bays. Embayment codes are: CB, Chincoteague Bay; NB, Newport Bay; SB, Sinepuxent Bay; IWB, Isle of Wight Bay; SMR, St. Martin River; AB, Assawoman Bay. Temp, temperature; Sal, salinity; Chl $a$, chlorophyll $a$; But-Fuco, 19'-Butanoyloxy-Fucoxanthin; Cteno, Ctenophores; CPUE, Catch Per Unit Effort.

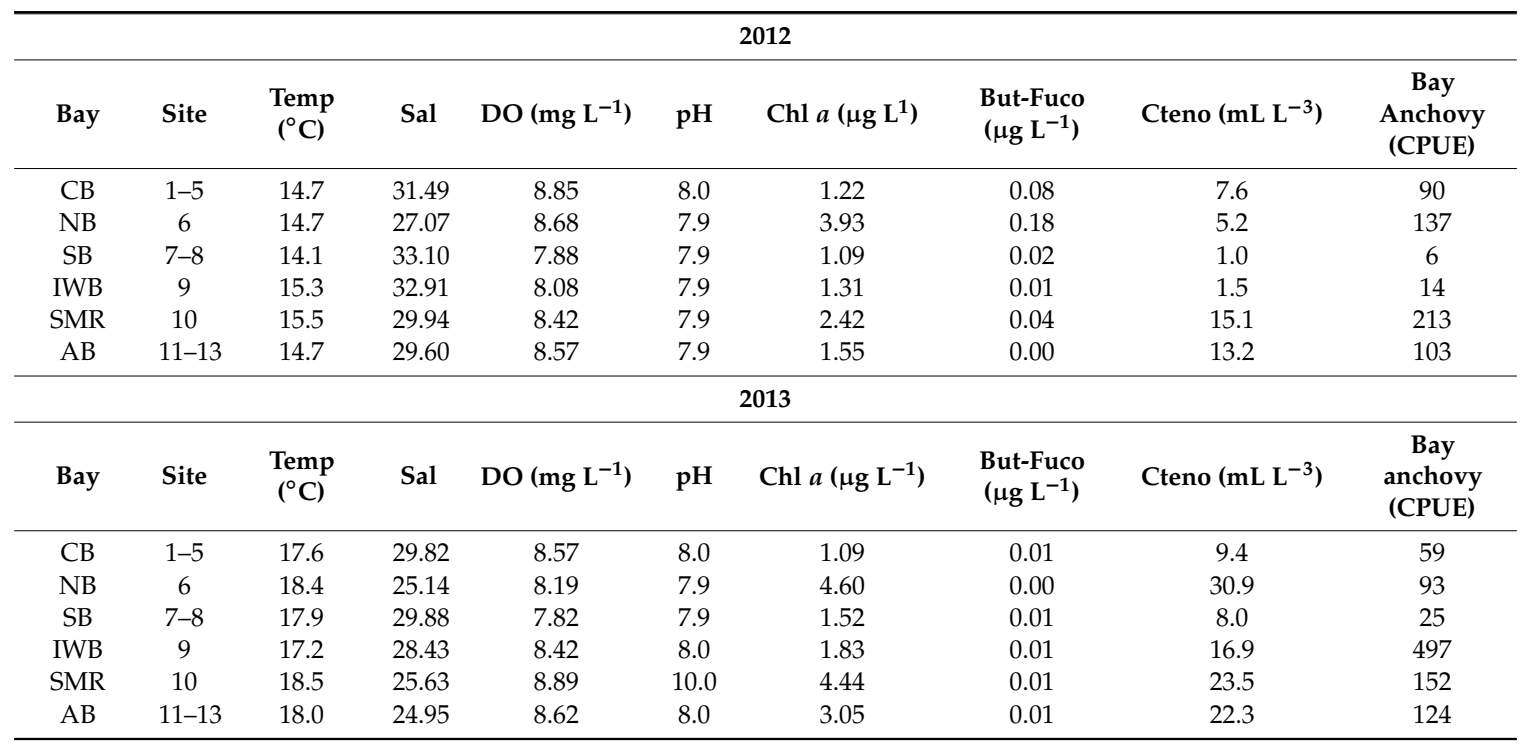

\subsection{Temporal Pattern of Mesozooplankton Abundance}

Mesozooplankton abundance expressed as individuals $\mathrm{m}^{-3}$ (ind. $\mathrm{m}^{-3}$ ) varied from 5 ind. $\mathrm{m}^{-3}$ (Site 12) in May 2012 to 410,509 ind. $\mathrm{m}^{-3}$ (Site 8) in September 2013. The average monthly abundance was high $\left(24,543\right.$ ind. $\left.\mathrm{m}^{-3}\right)$ in February, but peaked in early March $\left(36,878\right.$ ind. $\left.\mathrm{m}^{-3}\right)$ during winter of 2012; it declined to a relatively low level in spring and then gradually increased from summer through fall (Figure 3). Relatively high abundance $\left(30,032\right.$ ind. $\mathrm{m}^{-3}$ ) of mesozooplankton was observed in December 2012. A gradual decline was also observed from winter 2013 through early spring. Densities remained low (378 ind. $\mathrm{m}^{-3}$, May 2012) in spring and early summer, peaked $\left(34,828\right.$ ind. $\mathrm{m}^{-3}$ ) in September 2013 and then declined in fall.

Mesozooplankton abundance differed significantly between years (Table 2) in summer and fall $(\mathrm{p}<0.001)$, but not in winter and spring $(\mathrm{p}>0.05)$. In fall, abundance was significantly higher in 2012 than 2013 (Mann-Whitney $\mathrm{U}=261, \mathrm{~T}=2040.0, \mathrm{p} \leq 0.001$ ), but in summer, it was lower in 2012 than in $2013(\mathrm{U}=392.0, \mathrm{~T}=1909.0, \mathrm{p} \leq 0.001)$. 
Seasonal and spatial patterns of abundance of mesozooplankton are presented in Figure 4. For each of the seasons examined, there were no significant differences among sites in mesozooplankton abundance (ANOVA, $\mathrm{p}>0.05$ ) except in summer 2012 (ANOVA, $\mathrm{p}=0.05$ ) when the highest density was recorded (Figure 4 and Table 3) at Site 7 (Tukey test, $\mathrm{p}<0.05$ ). When mesozooplankton abundance was compared among bays, higher abundance was recorded in Sinepuxent Bay than in any other bay in winter and summer 2012 (ANOVA, $\mathrm{p}<0.05$ ), as shown in Table 3.

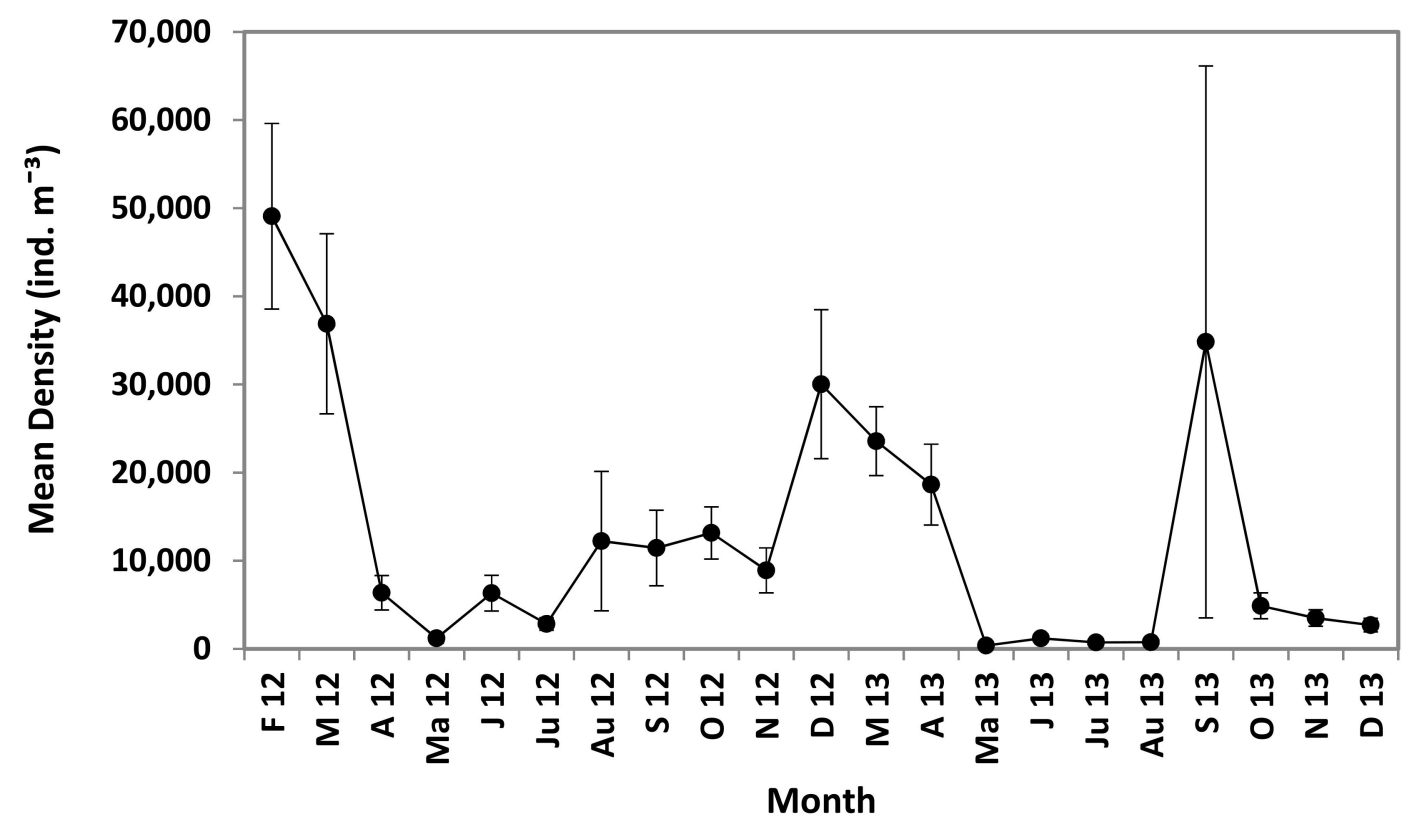

Figure 3. Temporal pattern in the abundance $( \pm S E)$ of mesozooplankton in the Maryland Coastal Bays.

Table 2. Seasonal average densities (ind. $\mathrm{m}^{-3}$ ) of mesozooplankton in the Maryland Coastal Bays. Winter, January-March; spring, April-June; summer, July-September; fall, October-December.

\begin{tabular}{cccc}
\hline \multicolumn{4}{c}{ Mean Density (SE) } \\
\hline Season & $\mathbf{2 0 1 2}$ & $\mathbf{2 0 1 3}$ & P-Value \\
\hline Winter & $30,710(5759)$ & $23,564(3907)$ & 0.870 \\
Spring & $4653(1009)$ & $6738(2025)$ & 0.337 \\
Summer & $8837(3009)$ & $12,109(10,489)$ & $\leq 0.001$ \\
Fall & $17,368(3364)$ & $3,697(634)$ & $\leq 0.001$ \\
\hline
\end{tabular}

Table 3. One-way ANOVA result of analyses comparing mesozooplankton density among sampling sites and embayments of the Maryland Coastal Bays in the different seasons in 2012 and 2013. d.f, degree of freedom; Fs, F-value; $P$, probability value; ${ }^{*} 0.05>p>0.01 ; n . s, p>0.05$. There were insufficient data to perform ANOVA in winter 2012.

\begin{tabular}{ccccccccccc}
\hline Year & Season & Sites & \multicolumn{7}{c}{ Embayments } \\
\hline & & d.f & F & $\mathbf{P}$ & & d.f & F & P & \\
\hline \multirow{3}{*}{2012} & Winter & 12 & 1.59 & 0.210 & n.s & 4 & 3.22 & 0.027 & $*$ \\
& Spring & 12 & 0.93 & 0.532 & n.s & 4 & 1.81 & 0.137 & n.s \\
& Summer & 12 & 2.14 & 0.050 & $*$ & 4 & 2.62 & 0.042 & $*$ \\
& Fall & 12 & 1.16 & 0.360 & n.s & 4 & 1.51 & 0.215 & n.s \\
\hline \multirow{2}{*}{2013} & Winter & 12 & - & - & & 4 & 3.01 & 0.092 & n.s \\
& Spring & 12 & 0.32 & 0.979 & n.s & 4 & 0.83 & 0.535 & n.s \\
& Summer & 12 & 1.00 & 0.476 & n.s & 4 & 1.10 & 0.379 & n.s \\
& Fall & 12 & 0.70 & 0.737 & n.s & 4 & 1.62 & 0.183 & n.s \\
\hline
\end{tabular}




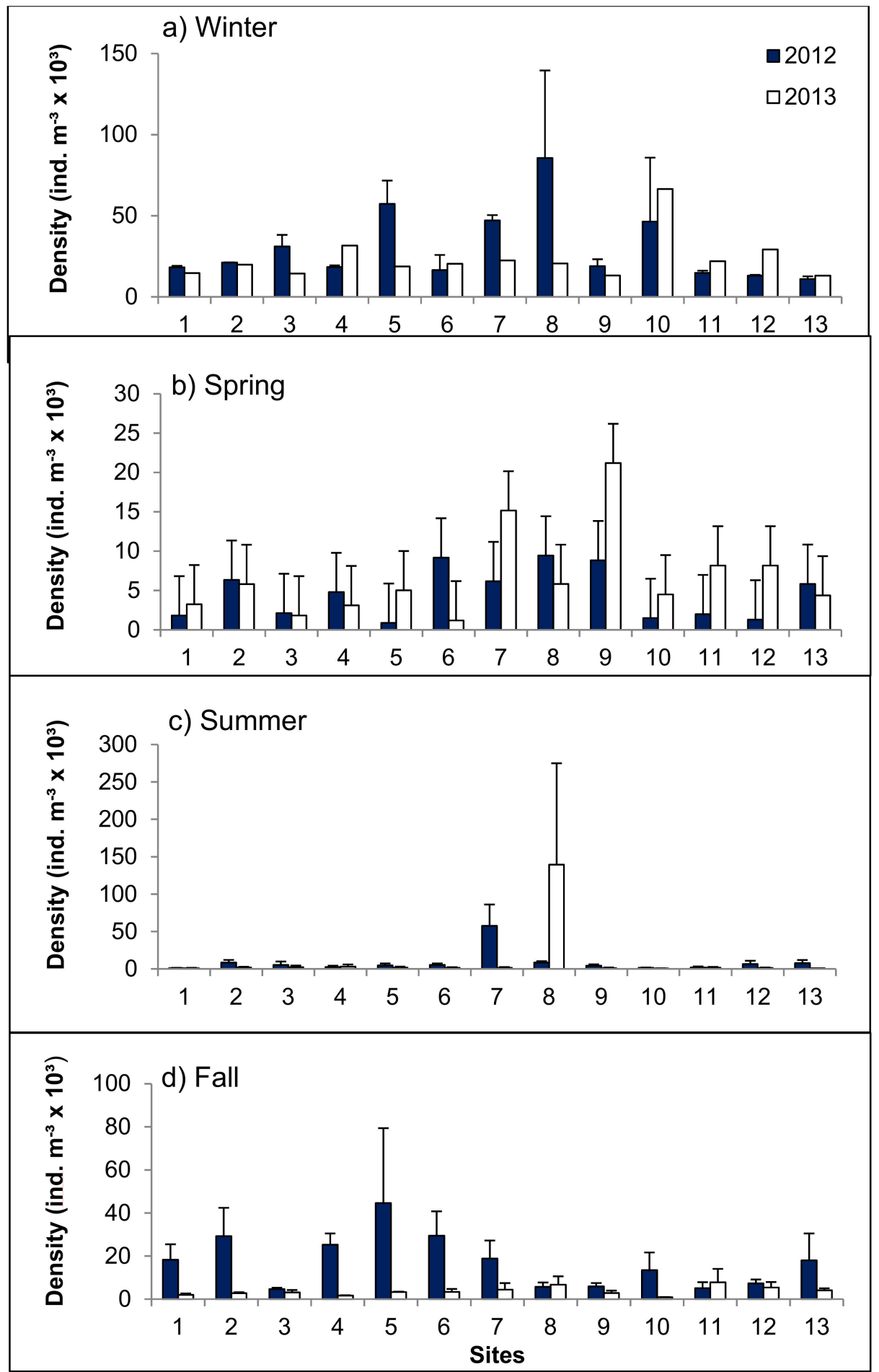

Figure 4. Spatial patterns in the densities (+SE) of mesozooplankton in the Maryland Coastal Bays in 2012 (year of below average freshwater discharge) and 2013 (year of above average freshwater discharge): (a) winter; (b) spring; (c) summer; and (d) fall.

3.3. Community Composition, Relative Abundance and Distribution of Non-Copepod Mesozooplankton in $M C B s$

Mesozooplankton community in the MCBs was represented by 14 major taxa dominated by copepods, but only groups that are relatively abundant are presented in Figure 5. Non-copepods 
contributed about $5 \%$ of the total mesozooplankton abundance. A detailed description of copepod species composition and abundance in the MCBs has been made [42].

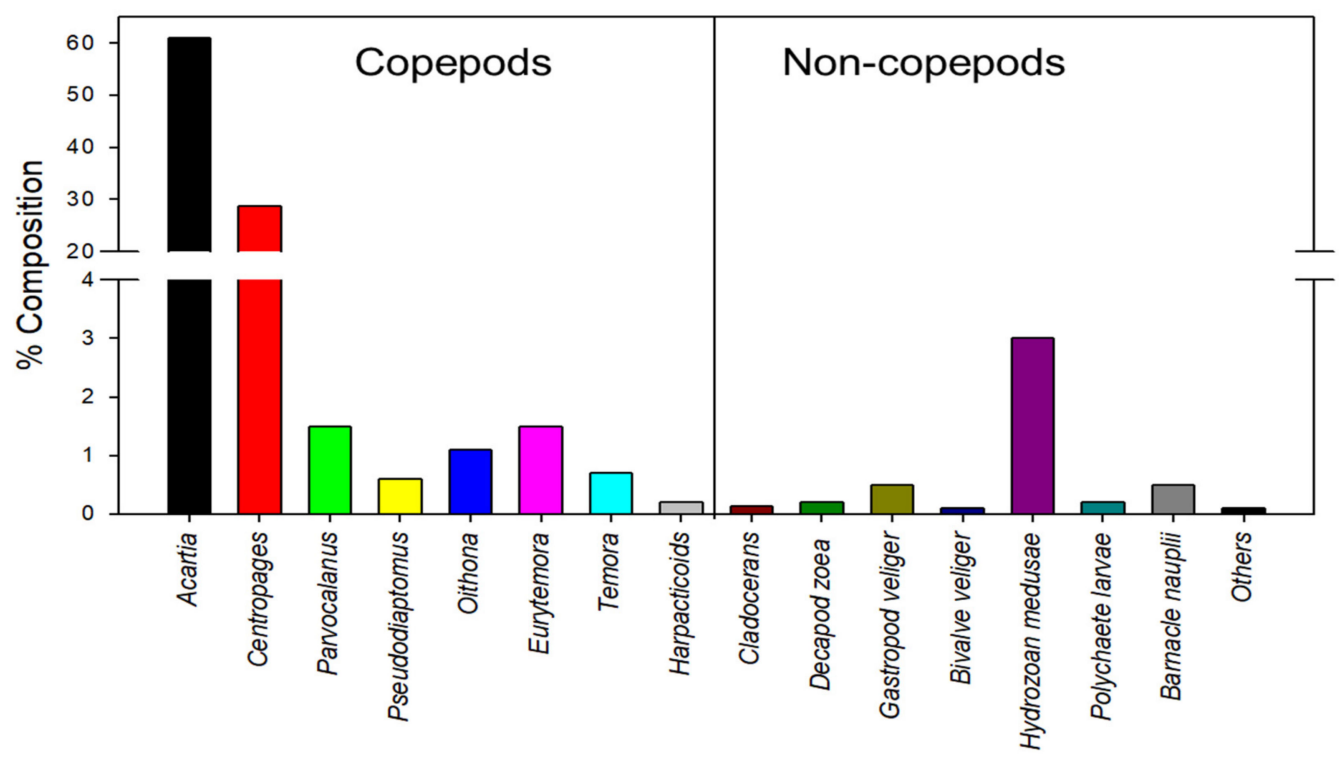

Figure 5. Mesozooplankton community composition in the Maryland Coastal Bays based on samples collected in 2012 and 2013.

The non-copepod community on the average was dominated by hydromedusae (3\%), followed by gastropod veliger $(0.5 \%)$, and barnacle nauplii ( $0.5 \%)$ (Figure 5$)$. Cladocerans $(0.1 \%)$ and larval stages of decapods $(0.2 \%)$, polychaetes $(0.2 \%)$, bivalves $(0.1 \%)$, and fish $(0.1 \%)$ were also relatively abundant within the non-copepod community. Larvaceans, nematodes, amphipods, and isopods made up $<1 \%$ of the zooplankton community.

The percentage contribution of non-copepods to total zooplankton abundance was as high as $98 \%$ at Site 12 (AWB) in the summer when copepod relative abundance was low. Monthly averaged contribution varied between $0-31.9 \%$ in 2012 and $0.4-76.5 \%$ in 2013 (Figure 6). Non-copepods were most represented in May 2012 and June 2013.

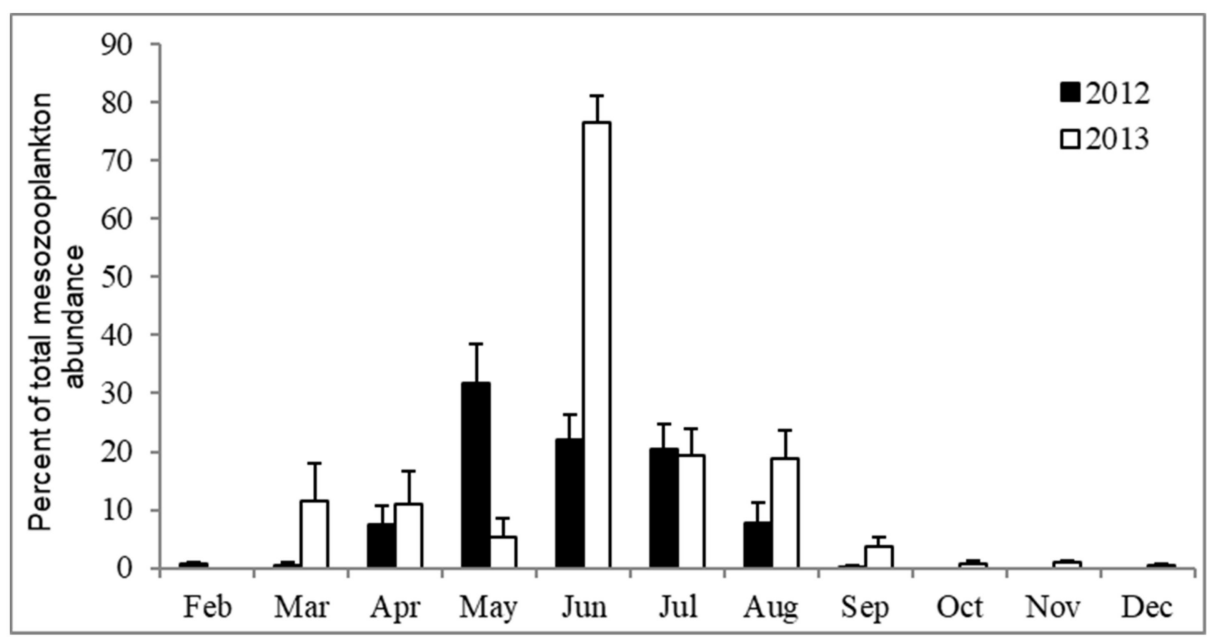

Figure 6. Percentage contribution by number of non-copepod taxa to total mesozooplankton abundance $(+\mathrm{SE})$ in the Maryland Coastal Bays.

In 2012, barnacle nauplii were the most abundant non-copepods, with mean density of 810 ind. $\mathrm{m}^{-3}$ in Newport Bay (Figure 7a,b). Annual peaks were observed in April 2012 (368 ind. $\mathrm{m}^{-3}$ ) and 
September 2013 (102 ind. $\mathrm{m}^{-3}$ ). The maximum barnacle nauplii density (4645 ind. $\mathrm{m}^{-3}$ ) was attained in April 2012 in Newport Bay and mean abundance of barnacle nauplii was significantly higher in Newport Bay than in other embayments (ANOVA, $p=0.02$ ). Although, barnacle nauplii were absent in fall 2012, they were present in all seasons in 2013 (Figure 8a-d). Maximum density in 2013 was 1119 ind. $\mathrm{m}^{-3}$ in September at Site 3 (Chincoteague Bay). Barnacle nauplii were more abundant in spring and summer than in the fall and winter (ANOVA, $\mathrm{p}<0.001$ ).

a) 2012

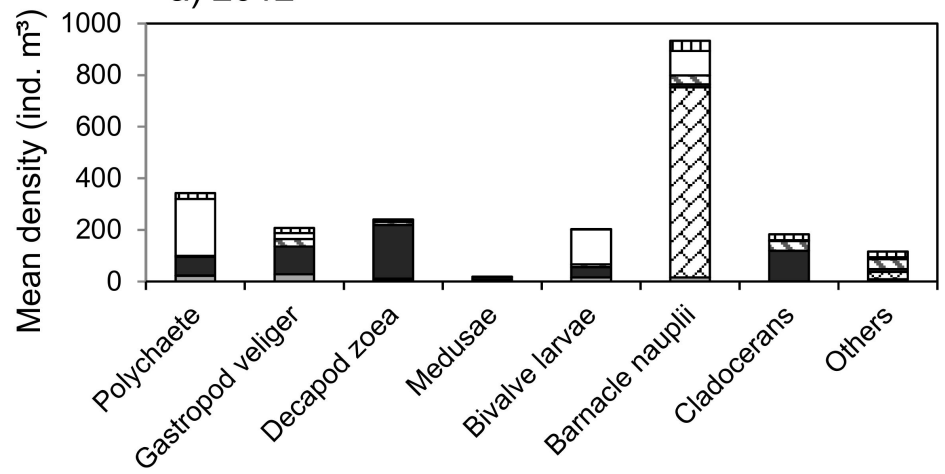

b) 2012
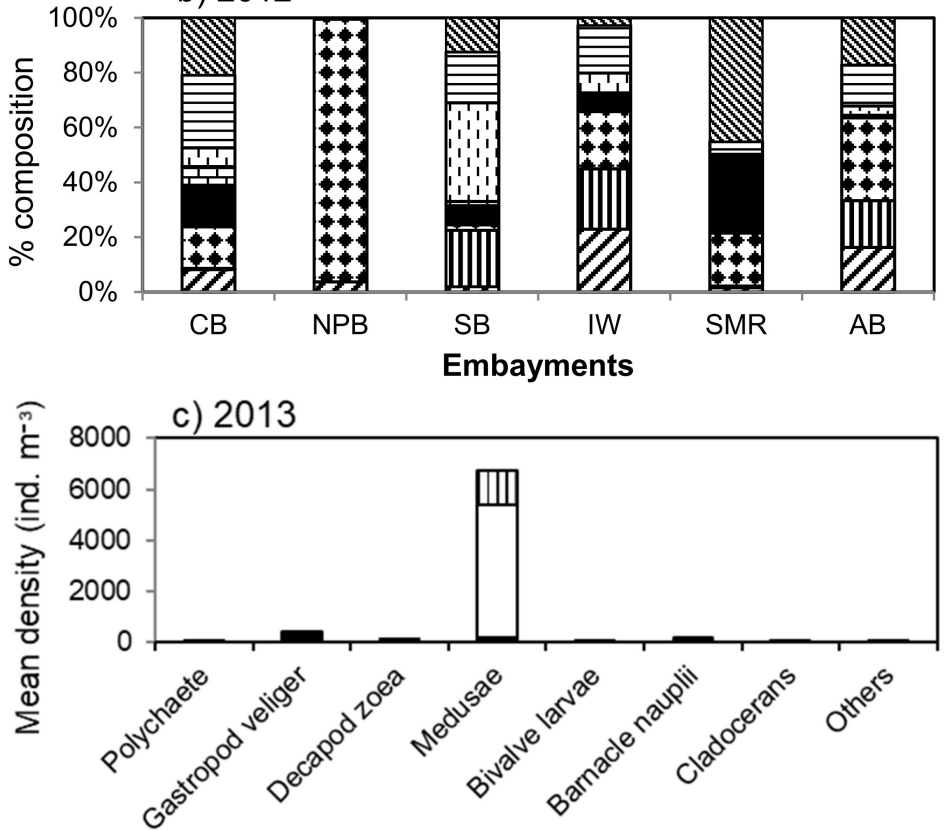

d) 2013

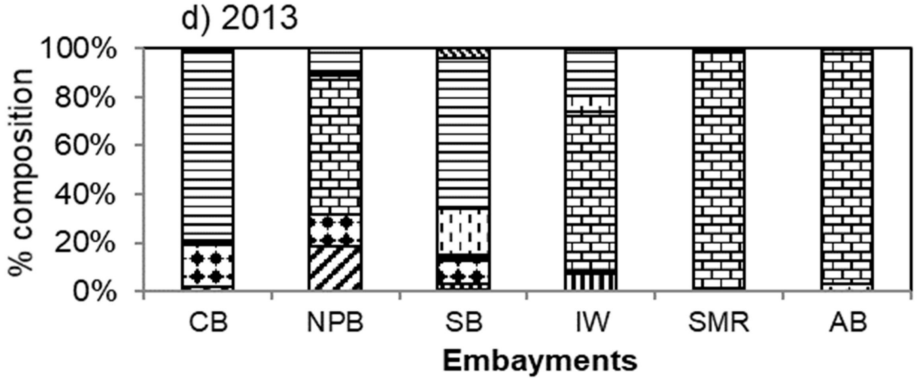

$\square \mathrm{AB}$

口SMR

هIW

aB

$\triangle N P B$

$\square \mathrm{CB}$

\$ Polychaete

घGastropod veliger

口Decapod zoea

$\rightarrow$ Medusae

- Bivalve larvae

w. Barnacle nauplii

- Cladocerans

च Others

$\square A B$

口SMR

QIW

- $S B$

$\square N P B$

$\square C B$

\section{ه Polychaete}

日Gastropod veliger

uDecapod zoea

aMedusae

- Bivalve larvae

هarnacle nauplii

mCladocerans

- Others

Figure 7. Spatial distribution, abundance $(\mathbf{a}, \mathbf{c})$ and percentage composition $(\mathbf{b}, \mathbf{d})$ of non-copepod mesozooplankton in the MCBs during 2012 (below average) and 2013 (above average) freshwater discharge from winter to summer. CB, Chincoteague Bay; NB, Newport Bay; SB, Sinepuxent Bay; IWB, Isle of Wight Bay; SMR, St. Martin River; AB, Assawoman Bay. 

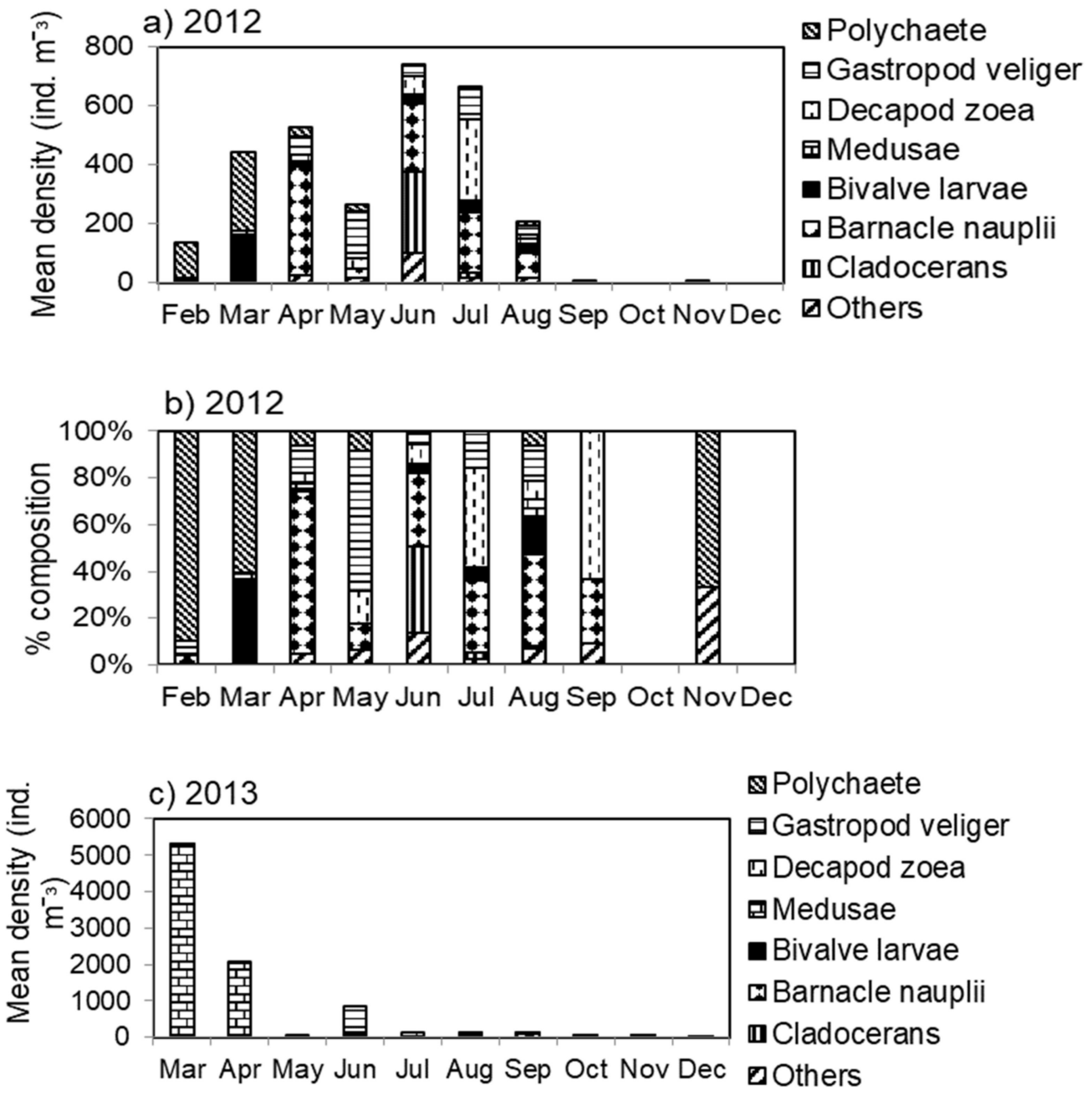

d) 2013

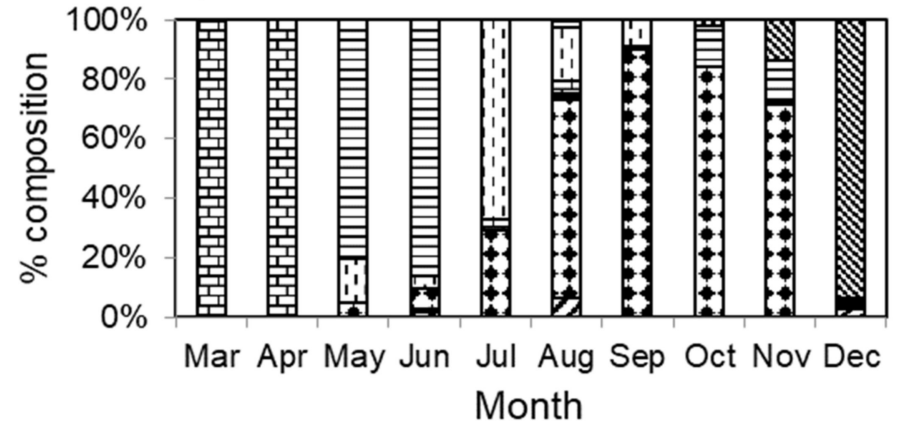

Figure 8. Temporal patterns in abundance $(\mathbf{a}, \mathbf{c})$ and percent contribution $(\mathbf{b}, \mathbf{d})$ of non-copepod mesozooplankton in the Maryland Coastal Bays during 2012 (year of below average freshwater discharge from winter to summer) and 2013 (year of above average freshwater discharge from winter to summer).

In 2013, hydromedusae were the most abundant non-copepod mesozooplankton (Figure 7c,d). Mean densities as high as 1367 ind. $\mathrm{m}^{-3}$ and 5156 ind. $\mathrm{m}^{-3}$ were recorded in Assawoman Bay and St. Martin River, respectively, in 2013. Hydromedusae were not observed at St. Martin River and Newport Bay sites in 2012 and also were not observed in Sinepuxent Bay in 2013 (Figure 7b,d). They were present from March to August in 2012 and from March to September in 2013, but were not found in May 2013 (Figure 8a-d). Average hydromedusae abundance was less than 20 ind. $\mathrm{m}^{-3}$ each month 
and at all sampling sites in 2012. Monthly mean densities peaked in April, 2012 (16 ind. $\left.\mathrm{m}^{-3}\right)$ and in March 2013 (5252 ind. $\mathrm{m}^{-3}$ ). The highest density recorded in 2013 (50,399 ind. $\mathrm{m}^{-3}$, March, Site 10) was 298 times greater than the highest density (181 ind. $\mathrm{m}^{-3}$, March, Site 5) in 2012.

Gastropod larvae were intermittently present and their monthly mean density reached a peak in May 2012 (158 no $\mathrm{m}^{-3}$, Figure 8a). A secondary peak (103 ind. $\left.\mathrm{m}^{-3}\right)$ occurred in July of the same year. Mean density in 2013 peaked in June (721 ind. $\left.\mathrm{m}^{-3}\right)$. Gastropod larvae were abundant $\left(107 \mathrm{ind} . \mathrm{m}^{-3}\right)$ in Sinepuxent Bay, but were not observed in Newport Bay in 2012 (Figure 7a-b). A maximum density (1299 ind. $\mathrm{m}^{-3}$ ) of the larvae was observed in May 2012 at Site 7 (Sinepuxent). In 2013, maximum density (1852 ind. $\mathrm{m}^{-3}$ ) occurred at Site 4 (Chincoteague Bay) in June. Gastropod larvae were least abundant in Assawoman Bay $\left(2\right.$ ind. $\left.\mathrm{m}^{-3}\right)$ in 2013.

Polychaete larvae occurred from February through August in 2012 and were most abundant (266 ind. $\mathrm{m}^{-3}$ ) in March (Figure 8a). Mean polychaete larval densities never exceeded 10 ind. $\mathrm{m}^{-3}$ in 2013, occurred sporadically, and were most abundant in March (9 ind. $\left.\mathrm{m}^{-3}\right)$. Polychaete larvae were more abundant in 2012 than 2013 (Mann-Whitney U-test, $p=0.0002$ ). Peak numbers were 2384 ind. $\mathrm{m}^{-3}$ in March 2012 at Site 10 located in St. Martin River and 60 ind. $\mathrm{m}^{-3}$ in March 2013 at Site 5 in Chincoteague Bay (Figure 7a-d).

Bivalve larvae were present from February through August in 2012 (Figure 8a), but their occurrence was irregular in 2013 (Figure 8c) with mean monthly densities $<5$ ind. $\mathrm{m}^{-3}$. Bivalve larvae were better represented in plankton samples from 2012 than 2013 (Mann-Whitney U-test, $p=0.001$ ) and relatively abundant in March during both years (Figure 7). Average density was 161 ind. $\mathrm{m}^{-3}$ in March 2012, and 4 ind. $\mathrm{m}^{-3}$ in March 2013. Maximum densities of 1490 ind. $\mathrm{m}^{-3}$ at Site 10 (St. Martin River) in 2012 and 58 ind. $\mathrm{m}^{-3}$ at Site 8 (Sinepuxent Bay) in 2013 were recorded in March. Bivalve larvae were only found in Sinepuxent Bay and Isle of Wight Bay (Site 9) in 2013, but their distribution in 2012 was widespread except at Sites 3 and 6 where they were not observed. Densities did not differ significantly amongst embayments (ANOVA, $\mathrm{p}=0.12$ ).

Cladocerans (Evadne nordmanni, E. spinifera, Pseudoevadne tergestina, Pleopis polyphemoides, Podon intermedius) were most abundant in Sinepuxent and Isle of Wight Bays (ANOVA, $\mathrm{p}=0.002$ ) during summer and were absent from Newport Bay (Figure 7b).

Decapod larvae (shrimps and crabs) were prevalent in Sinepuxent Bay where they occurred from March through November in 2012 and 2013 (Figure 7; Figure 8). In July, they comprised 42\% and 67\% of non-copepod zooplankton abundance, and 10\% and $11 \%$ of total mesozooplankton abundance in 2012 and 2013, respectively. Larval stages of crabs Panopeus herbstii, Neopanope texana, Uca spp. and Pinnixia spp. were observed in zooplankton samples collected in 2012. Zoeae of Callinectes sapidus, Rhithropanopeus harrisii, Ovalipes ocellatus, Cancer irroratus, Emerita spp., Hemigrapus sp., Libinia dubia, Ocydopode spp., Petrolisthes armatus, and Lepidopa websteri were also present.

Fish larvae were first observed in April 2012 (mean: 16 ind. $\mathrm{m}^{-3}$ ) when they were most abundant (Figure 8). They were observed in December 2013 ( 0.1 ind. $\left.\mathrm{m}^{-3}\right)$, but mean densities were very low. The highest density of fish larvae (202 ind. $\mathrm{m}^{-3}$ ) was observed at Site 6 in Newport Bay (April 2012).

Larvaceans occurred from April to June 2012 and in August 2013. Average densities ranged from 1 to 5 ind. $\mathrm{m}^{-3}$. The maximum density of larvaceans was 23 ind. $\mathrm{m}^{-3}$, at Site 8 (Sinepuxent Bay) in August, 2013. Other non-copepods irregularly found in samples included amphipods, isopods, nematodes, and ostracods.

\subsection{Relationships Between Non-Copepod Mesozooplankton and Environmental Factors}

In 2012 (Figure 9a), the first two CCA axes explained $47.1 \%$ of the cumulative percentage variance of taxa-environment relationship and the correlations were 0.89 and 0.89 for the first and second axes, respectively. The biplot in 2012 showed that the main variability (29.6\% of variance) was due to the positive association of larval shrimp and bivalves with salinity $(\mathrm{p}=0.046)$. In contrast, barnacle nauplii and ostracods were negatively related to salinity $(\mathrm{p}<0.05)$. Gastropod and polychaete larvae showed 
a positive relationship with $\mathrm{pH}(\mathrm{p}=0.022)$, while crab zoeae, Evadne spp. and Pleopis sp. related inversely to $\mathrm{pH}$. Hydromedusae neither associated closely with salinity nor $\mathrm{pH}$ in 2012.

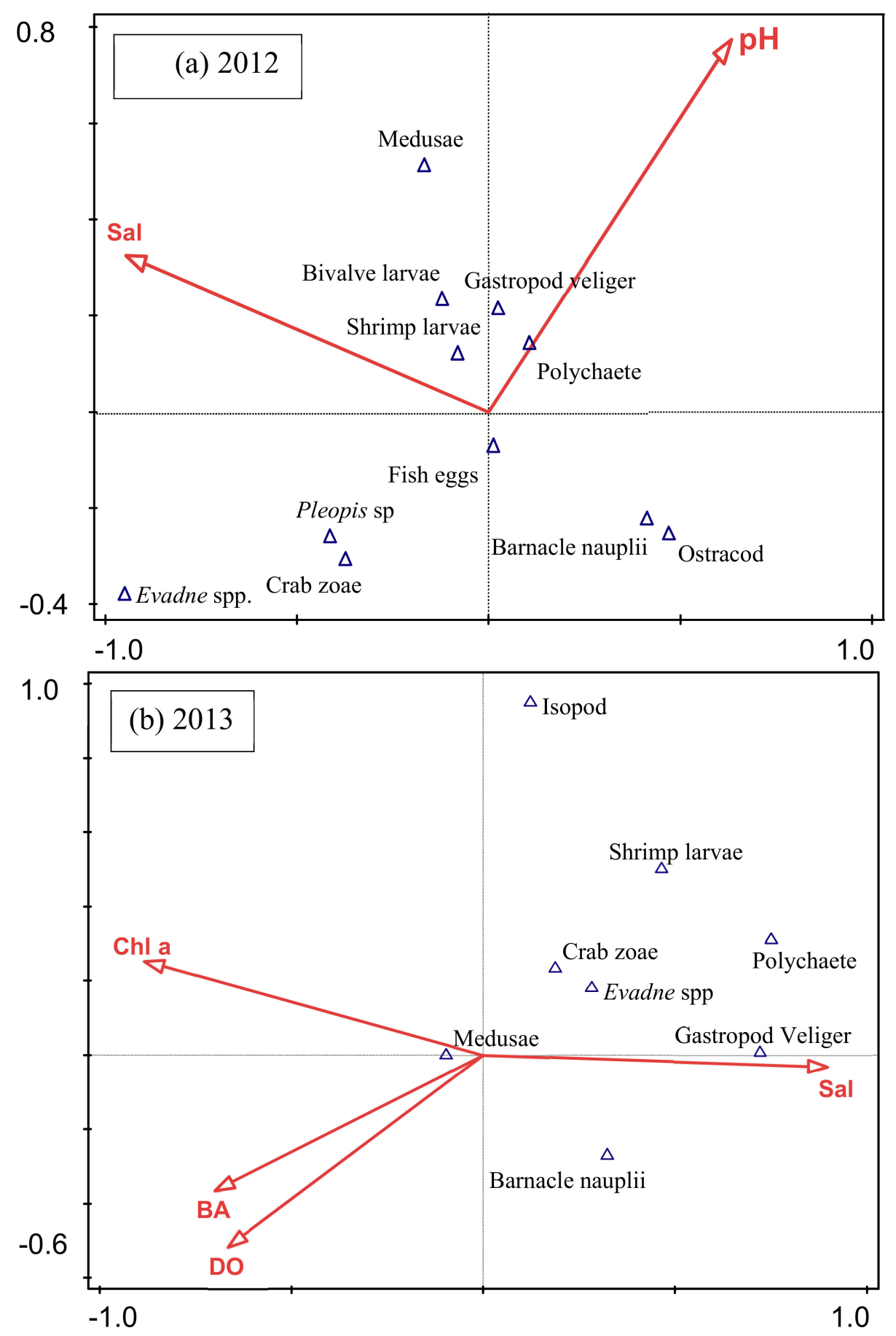

Figure 9. Results of CCA analysis showing environmental variables and taxa relationships in: 2012 (a); and 2013 (b) in MCBs. BA, bay anchovy; DO, Dissolved oxygen; Sal, Salinity; Chl $a$, Chlorophyll $a$.

In 2013 (Figure 9b), the first two axes of the CCA explained 70\% of the cumulative variation in taxa-environment relationship, and the correlation was 0.98 for the first axis and 0.91 for the second axis. The taxa-environment biplot (Figure $9 \mathrm{~b}$.) showed that the variability (63.7\% of variance) was accounted for by the positive association of gastropod veliger with salinity $(p=0.026)$, and inverse relationship of hydromedusae to salinity $(\mathrm{p}<0.05)$. Barnacle larvae were negatively aligned to Chl. $a$ 
$(\mathrm{p}=0.034)$; bay anchovy larvae were positively correlated to $\mathrm{DO}(\mathrm{p}=0.04)$, which was also plotted inversely with cladocerans, decapod zoae and polychaete larvae. Temperature, $\mathrm{pH}$, and ctenophores correlated strongly with $\mathrm{DO}$ and were not selected by the model.

\subsection{Mesozooplankton Diversity}

The diversity of mesozooplankton varied temporally and spatially and was affected by salinity such that diversity was higher at higher salinity than at lower salinity (Figure 10). The Shannon-Wiener diversity index was high $(\geq 2.5)$ in 2012 at all sites except at Site $6\left(\mathrm{H}^{\prime}=2.2\right)$ in Newport Bay with the lowest diversity (Figure 10). Diversity index value in Newport Bay (Site 6) in $2012\left(\mathrm{H}^{\prime}=2.2\right)$ was slightly lower than in $2013\left(\mathrm{H}^{\prime}=2.3\right)$. On the average, diversity was significantly higher $(\mathrm{t}=6.2$; $\mathrm{p} \leq 0.001)$ in 2012 than in 2013. Sinepuxent Bay supported the highest diversity $\left(\mathrm{H}^{\prime}=2.8\right.$ in 2012; $\mathrm{H}^{\prime}=2.6$ in 2013) of mesozooplankton in both years. Diversity decreased from Sinepuxent Bay (Sites 7 and 8) close to the Ocean City Inlet to Assawoman Bay (Site 13) in the northern MCBs in both 2012 and 2013. Likewise, diversity in Chincoteague Bay decreased from Site 5 to Sites 1 and 2 in both years.
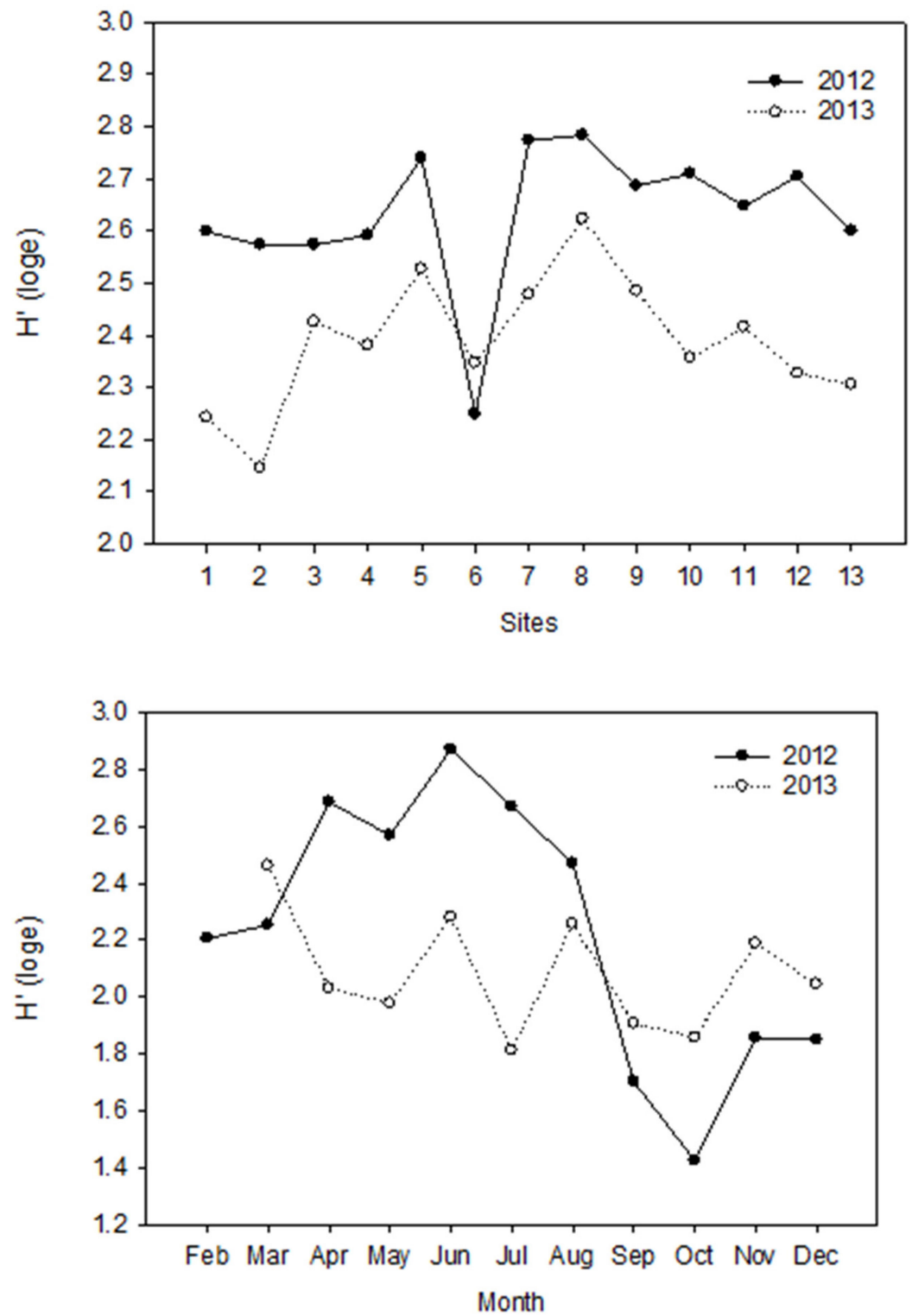

Figure 10. Spatial (top) and seasonal (bottom) patterns in Shannon-Wiener diversity index of mesozooplankton in the MCBs in 2012 and 2013 from winter to summer. 
Diversity was higher in spring and summer $\left(\mathrm{H}^{\prime}>2.4\right)$ than in fall $\left(\mathrm{H}^{\prime}<1.9\right)$ of 2012. In 2013, diversity in March and from September to December was higher $(t=-2.3 ; p \leq 0.06)$ than diversity in 2012. Periods of maximum and minimum diversity index values were different in 2012 and 2013. Mesozooplankton was most diverse in June $\left(\mathrm{H}^{\prime}=2.9\right)$ and March $\left(\mathrm{H}^{\prime}=2.5\right)$, but least diverse in October $\left(\mathrm{H}^{\prime}=1.4\right)$ and July $\left(\mathrm{H}^{\prime}=1.8\right)$ in 2012 and 2013, respectively.

When examined spatially, diversity indices values in 2012 were significantly correlated negatively with Chl. $a(\mathrm{r}=-0.7, \mathrm{p}=0.01)$ and positively with salinity $(\mathrm{r}=0.7, \mathrm{p}=0.02)$, but not with But-fuco $(\mathrm{r}=-0.5, \mathrm{p}=0.08)$. In 2013, diversity also correlated positively with salinity $(\mathrm{r}=0.3, \mathrm{p}<0.050)$. All other environmental factors were weakly correlated with mesozooplankton spatial diversity in 2013 , and no significant relationship was observed ( $\mathrm{p}>0.05$ ). With respect to monthly diversity, $\mathrm{H}^{\prime}$ was significantly correlated with ctenophores $(\mathrm{r}=0.7, \mathrm{p}=0.02)$ in 2012 , but not in $2013(\mathrm{r}=-0.1$, $\mathrm{p}=0.9)$. Other variables such as temperature $(\mathrm{r}=-0.4, \mathrm{p}=0.2)$ and salinity $(\mathrm{r}=-0.4, \mathrm{p}=0.3)$ showed weak negative correlations with diversity in 2013.

\section{Discussion}

This is the first study to describe mesozooplankton assemblage dynamics in the MCBs. The mesozooplankton composition, abundance and diversity varied spatially and temporally in the MCBs, driven in part by fluctuations in environmental factors, particularly salinity. Lower salinity due to increased freshwater input coupled with higher ambient temperature in 2013 (Figure 2) relative to that of 2012, perhaps promoted high densities of hydromedusae in winter and early spring. Gelatinous zooplankton can exert high predatory pressure on crustacean zooplankton species as well as on gastropod veligers, barnacle nauplii, polychaete larvae, and ichthyoplankton (fish larvae) [32,43-47]. The feeding rate of ctenophores, in particular, increases with water temperature [48], possibly contributing to the decline in annual peak abundance observed for some non-copepod taxa (polychaete larvae, ostracods, bivalve and fish larvae). Nevertheless, the high freshwater inflow associated with Hurricane Sandy in fall 2012 accompanied by the relatively low salinity that occurred through spring 2013 might have contributed to the observed low abundances of the taxa in the MCBs.

\subsection{Mesozooplankton Community Composition and Taxa-Environment Relationships}

The percent contribution of non-copepods (e.g., decapod larvae, cladocerans) to mesozooplankton abundance in this study was highest in late spring and early summer when copepod density was relatively low [42]. Similar observations were made in the lower Narragansett Bay [16] and in other mid-Atlantic estuaries $[6,19,35,49]$. The increase in non-copepod taxa relative abundance that occurred when copepod density was low is important since they serve as alternate prey for zooplanktivorous fishes. Bay anchovy is abundant in summer in MCBs [50], and the juveniles usually make up the majority of estuarine bay anchovy population biomass in summer and fall [51]. Although copepods contribute the bulk of bay anchovy's diet, non-copepod taxa, especially larvae of barnacles, bivalves, and polychaetes, as well as amphipods, crab zoeae, mysids, ostracods, cladocerans, and ichthyoplankton seasonally dominate the diet in mid-Atlantic estuaries such as Long Island Sound, Cheseapeake Bay and MCBs $[8,9,52-55]$.

Temporal variations in freshwater discharge and salinity influenced the relative abundance of mesozooplankton taxa. For example, Barnacle nauplii dominated the non-copepod community, especially in Newport Bay from January to August 2012. During this period, freshwater discharge into MCBs was relatively low and salinity was high. Naupliar stages of barnacles were absent in fall of 2012, which might have been due to the dramatic reduction in salinity caused by excessive rainfall that was associated with Hurricane Sandy that increased freshwater inputs into the system possibly increasing mortality of the larvae and perhaps the adult stages. Mortality of barnacle larvae is higher at low salinity $(<6)$ than at higher $(>14)$ salinity [56], and high rainfall with associated high freshwater discharge has been reported to depress the abundance of some species of barnacles. Higher densities of barnacles were collected during dry season than wet season in coastal lagoons in Panama [56] 
and in Lagos Harbor, Nigeria [57]. The salinity observed in the MCBs in spring of 2013 (wet year) was much higher (23-26) than the levels observed during the rainy season in these other lagoons, though the salinity in MCBs during the period Hurricane Sandy occurred might have been much lower than the values we recorded after the event. Spring and summer peaks of barnacle naupliar observed in the MCBs were also reported for the Delaware River estuary [19]. In 2013, a year of above average freshwater discharge into MCBs and lower salinity, hydromedusae dominated non-copepod community particularly in Assawoman Bay and at the mouth of St. Martin River. Larvae of polychaetes and bivalves, in addition to ostracods, and larvaceans, were better represented in the plankton in 2012 when salinity was higher, than in 2013 when salinity was lower. In estuaries that experience much horizontal gradient in salinity, seawater penetration can bring in zooplankton species from the coastal ocean during periods of low freshwater inputs [11].

There were seasonal changes in the relative abundance of mesozooplankton taxa in the MCBs. Hydromedusae were present from winter through summer, but scarce in fall (October-December). Hydromedusae were abundant in Delaware Bay River estuary during winter [18] and in Long Island estuary in April [49]. Polychaete and bivalve larvae were also abundant in winter to spring, with a shift in seasonal dominance from polychaetes to barnacles, gastropod larvae, crab zoea, barnacles, shrimps, and finally polychaete larvae in 2012. This seasonal pattern was different in 2013 when a shift in dominance of the major taxa occurred from hydromedusae to gastropod larvae, crab zoea, barnacles, and finally polychaetes.

The spatial distributions of mesozooplankton taxa were related to variations in salinity. Larvaceans were positively correlated to salinity, and found only in Sinepuxent Bay close to the Ocean City inlet in 2013. Bivalve larvae also showed a similar preference for high salinity bay areas in 2013 , and gastropod larval densities decreased at sites near the mouths of MCBs tributaries. The relatively high abundance of barnacle nauplii in Newport Bay and St. Martin River in both years as well as the occurrence of polychaete and bivalve larvae in high abundance in St. Martin River in the dry year (2012) and within the open waters of Sinepuxent Bay in the wet year (2013), suggests that salinity is an important factor that influenced their distributions and abundance. As salinity increases towards the ocean, clams, crustaceans and polychaete worms dominate the benthos of the coastal bays [27], thus accounting for the high abundance of meroplanktonic larvae of these organisms around Sinepuxent Bay. The occurrence of gastropod and polychaete larvae in high abundance in embayments closest to the coastal ocean (downstream) is contrary to the findings in Pagan River, a sub-estuary of Chesapeake Bay [17] and in Mondego estuary, Western Portugal [58] where the larvae were abundant upstream, although this might be due to differences in the species reported in the systems. In the Delaware River estuary, polychaete larvae occurred from the entrance of the river to the middle of the bay and peaked in abundance from winter to spring [19]. The lowest salinity at which they were observed was 24.1. In this study, annual peaks in the abundance of polychaete larvae were recorded at salinity levels $>30$.

\subsection{Occurrence of Blue Crab Larvae in the MCBs}

Blue crab, C. sapidus zoeae, were common in July in this study which is similar to the month during which they were observed by other investigators in nearby estuaries [18,37]. The study confirms what was previously suspected based on the capture of gravid females by the MD DNR that blue crabs spawn in the MCBs. Blue crab zoeae were most prevalent in Sinepuxent Bay and the northern bays and rarely occurred in southern bay areas with adequate salinity for larval development, although no sampling occurred near the Chincoteague Inlet in Virginia. This supports results of previous studies that indicated that blue crabs hatch their eggs near the mouth of estuaries [6,22]. The occurrence of zoeae at sites located in Assawoman Bay close to tributary creeks, however, suggests that spawning occurs not only close to the Ocean City Inlet, but also in areas that are some distance away from the inlet. It is also possible that crab larvae that hatched near the inlets were dispersed into Assawoman Bay by waves and tidal action. The proximity of spawning locations to the inlet enhances easy transportation of zoeae from the MCBs into the nearby continental shelf waters where further development takes 
place [22,25]. Additional studies are needed, however, to determine if blue crab larvae complete their development from zoeae to megalopae within the MCBs.

\subsection{Diversity of Mesozooplankton}

Mesozooplankton assemblage was most diverse in spring and summer of 2012 when salinity was relatively high, especially in areas close to the Ocean City Inlet, connecting the bays to the Atlantic Ocean. Intrusion of seawater in estuaries can act as a major driver for zooplankton diversity [59]. In Pearl River estuary China, zooplankton diversity and species richness were enhanced in the middle and lower portions with high diversity at salinity level $>25$ [11]. The higher zooplankton diversity in spring and summer months in 2012 might have been contributed by the increase in the abundance of cladocerans, decapod larvae, and other meroplanktonic forms in the system during that period, some of which were likely transported into the bays from coastal ocean by tidal action.

The most diverse assemblage was observed in areas with high salinity, but low chlorophyll $a$. The observed negative correlation between chlorophyll $a$ and diversity was because chlorophyll $a$ levels were higher in areas close to MCBs tributaries (Newport Bay and St. Martin River) with lower salinity and high nutrient levels due to freshwater inflow [38,60], which also had lower mesozooplankton diversity than in areas close to the inlets. Howson et al. [35] observed higher zooplankton diversity in the southern bay of the Barnegat Bay, NJ, with more oceanic influence and less anthropogenic impact, than in the more nutrient enriched northern bay.

\subsection{Implications of Temporal Variability in Environmental Factors on Mesozooplankton}

Variability in freshwater discharge altered salinity and influenced the abundance and distribution of mesozooplankton in the MCBs. High freshwater discharge that began in fall 2012 and continued through spring 2013 lowered salinity that likely favored hydromedusae whose abundance was highest in March and April, but perhaps disfavored bivalve and barnacle larvae. During this period, salinity was about 23 (March) and 26 (April) compared with about 30.5 (March) and 34 (April) in 2012. Salinity has been reported to influence the abundance and distribution of hydromedusae in other estuaries $[61,62]$. In Mississippi Sound, the incidence of hydromedusae was highest at 25.1 to 30 below and above which the abundance decreased [61]. With the occurrence and high abundance of hydromedusae, ctenophores [42] and scyphozoan jellyfish in the MCBs, and their documented negative impacts on the standing stock of planktonic communities [31,45,47,48], the slow rate of recovery of the hard clam population abundance in the MCBs is not surprising. This is because, peak abundance of bivalve larvae (March) coincided with the increase in the abundance of hydromedusae (March and April), which was followed by ctenophores (April-June) especially in 2013 when salinity was relatively low [42]. Hydromedusae are known predators of zooplankton [44] and when numerically abundant, are able to exert their potential maximum clearance impact [63]. Ctenophores as predators of bivalve larvae $[31,43,64]$ cause high mortality, with a potential of consuming up to $94.1 \%$ of the larvae during spawning periods [32].

Non-copepod zooplankton are important prey items for carnivorous zooplankton, larval fish, and adult planktivorous and forage fish such as bay anchovy. These organisms are relatively abundant when copepod abundance is low in the MCBs. During years with high freshwater input, the MCBs salinity levels in some areas may not be favorable for the development of some decapod crab zoeae and bivalve larvae (Mercenaria mercenaria) that prefer high salinity. In addition, the temperature range $\left(\sim 17-30^{\circ} \mathrm{C}\right)$ tolerated by M. mercenaria larvae is reduced when salinity decreases from the optimum range of 26-27 [65]. Thus, increased temperature, reduced salinity as well as high densities of gelatinous zooplankton (hydromedusae and ctenophores) can affect the breeding success of finfish and shellfish species in the MCBs. Gelatinous zooplankton can change food web dynamics and decrease recruitment of fish and shellfish populations by preying on the larval forms or via competition for zooplankton prey $[45,46]$. 


\section{Conclusions}

Results of this study indicate that variations in freshwater discharge affect the abundance, distribution and diversity of mesozooplankton in MCBs. These changes in mesozooplankton structure likely influence trophic relationships and recruitment of finfish and shellfish larvae to the adult populations. The percent contribution of non-copepods to mesozooplankton abundance in MCBs was highest in late spring and early summer when copepod density was relatively low. The composition and abundance of mesozooplankton differed between 2012 and 2013 such that barnacle larvae were the most abundant of non-copepod mesozooplankton, whereas hydromedusae were the most abundant group in 2013. Mesozooplankton diversity varied temporally and spatially, and was higher at higher salinity than at lower salinity. Seasonally, diversity was higher in spring and summer 2012 than in fall. Additionally, in 2012 when salinity was comparatively high because of low precipitation, diversity was higher than in 2013 when salinity was relatively low. Blue crab zoeae were common in the MCBs in the summer, especially in Sinepuxent Bay and the northern bays confirming that the adults spawn in the MCBs, although further studies are needed to determine if they complete their life cycle in the bays. Additional studies are also needed to investigate the predation rates of ctenophores, jellyfish and zooplanktivores such as bay anchovy on various zooplankton taxa. This will be useful for understanding the role of non-copepod community as alternate prey for fish in the MCBs during spring and summer minimum of copepods, and will also provide more information on the impact of predation on the survival of bivalve larvae and their recruitment to the adults.

Author Contributions: This study was conducted as a joint effort of all authors. Conceptualization, P.C. and E.U.O.; Methodology, E.U.O. and P.C.; Software, E.U.O.; Validation, E.U.O. and P.C.; Formal Analysis, E.U.O.; Investigation, E.U.O. and P.C; Resources, P.C.; Data Curation, E.U.O.; Writing-Original Draft Preparation, E.U.O.; Writing-Review and Editing, E.U.O. and P.C.; Visualization, E.U.O.; Supervision, P.C.; Project Administration, P.C.; and Funding Acquisition, P.C.

Funding: This publication was made possible by the National Science Foundation Center for Research Excellence in Science and Technology (NSF-CREST) award number (1036586) to the Center for the Integrated Study of Ecosystem Processes and Dynamics, University of Maryland Eastern Shore, and in part by the National Oceanic and Atmospheric Administration, Office of Education, Educational Partnership Program award number (NA16SEC4810007) to the Living Marine Resources Cooperative Science Center at the University of Maryland Eastern Shore. Its contents are solely the responsibility of the award recipient and do not necessarily represent the official views of the U.S. Department of Commerce, National Oceanic and Atmospheric Administration.

Acknowledgments: We would like to thank Kam Tang and Jamie Pierson for their valuable comments on the earlier draft of this manuscript, and Capt. Christopher Daniels (Boat Captain), Ozuem Oseji, Andres Morales-Nunez, Kingsley Nkeng, Chinwe Otuya, Abena Okyere Acheampong and Jessica Mazile for help with collection and enumeration of plankton samples. Data for bay anchovy were provided by Steve Doctor, Maryland Department of Natural Resources (MD DNR). Young Tsuei (DOEE) and Tracy Bishop (UMES) assisted with creation of map of the sampling sites.

Conflicts of Interest: The authors declare no conflict of interest. The funders had no role in the design of the study; in the collection, analyses or interpretation of data; in the writing of the manuscript or in the decision to publish the results.

\section{References}

1. Johnson, W.S.; Allen, D.M. Zooplankton of the Atlantic and Gulf Coasts: A Guide to Their Identification and Ecology, 2nd ed.; The Johns Hopkins University Press: Baltimore, MD, USA, 2012; 452p.

2. Kleppel, G.S. On the diets of calanoid copepods: Review. Mar. Ecol. Prog. Ser. 1993, 99, 183-195. [CrossRef]

3. Durbin, E.; Kane, J. Seasonal and spatial dynamics of Centropages typicus and C. hamatus in the western North Atlantic. Prog. Oceanogr. 2007, 72, 249-258. [CrossRef]

4. Verity, P.G.; Smetacek, V. Organism life cycles, predation, and the structure of marine pelagic ecosystems. Mar. Ecol. Prog. Ser. 1996, 130, 277-293. [CrossRef]

5. Bosch, H.F.; Taylor, W.R. Marine cladocerans in the Chesapeake Bay estuary. Crustaceana 1968, 15, 161-164. [CrossRef]

6. Sandifer, P.A. Distribution and abundance of decapod crustacean larvae in the York River Estuary and Adjacent Lower Chesapeake Bay, Virginia, 1968-1969. Chesap. Sci. 1973, 14, 235-257. [CrossRef] 
7. Steinberg, D.K.; Condon, R.H. Zooplankton of the York River. J. Coast. Res. 2009, 57, 66-79. [CrossRef]

8. Hartman, K.J.; Howell, J.; Sweka, J.A. Diet and daily ration of bay anchovy in the Hudson River, New York. Am. Fish. Soc. 2004, 133, 762-771. [CrossRef]

9. Klebasko, M.J. Feeding Ecology and Daily Ration of Bay Anchovy (Anchoa mitchilli) in the Mid-Chesapeake Bay. Master' Thesis, University of Maryland, College Park, MD, USA, 1991.

10. Mallin, M.A. Zooplankton abundance and community structure in a mesohaline North Carolina estuary. Estuaries 1991, 14, 481-488. [CrossRef]

11. Li, K.Z.; Yin, J.Q.; Huang, L.M.; Tan, Y.H. Spatial and temporal variations of mesozooplankton in the Pearl River estuary, China. Estuar. Coast. Shelf Sci. 2006, 67, 543-552. [CrossRef]

12. Kimmel, D.G.; Roman, M.R.; Zhang, X. Spatial and temporal variability in factors affecting mesozooplankton dynamics in Chesapeake Bay: Evidence from biomass size spectra. Limnol. Oceanogr. 2006, 51, 131-141. [CrossRef]

13. Elliot, D.T.; Kaufman, R.S. Spatial and temporal variability of mesozooplankton and tintinnid ciliates in a seasonally hypersaline estuary. Estuaries Coasts 2007, 30, 418-430. [CrossRef]

14. Shiganova, T.A. Invasion of the Black Sea by the ctenophore Mnemiopsis leidyi and recent changes in pelagic community structure. Fish. Oceanogr. 1998, 7, 305-310. [CrossRef]

15. Sage, L.E.; Herman, S.S. Zooplankton of the Sandy Hook Bay area, N.J. Chesap. Sci. 1972, 13, 29-39. [CrossRef]

16. Hulsizer, E. Zooplankton of the lower Narragansett Bay, 1972-1973. Chesap. Sci. 1976, 17, 260-270. [CrossRef]

17. Davis, L.N.; Marshall, H.G. Mesozooplankton distribution and abundance in the Pagan River: A nutrient enriched sub-estuary of the James River, Virginia. Va. J. Sci. 1998, 49, 151-162.

18. Deevey, G.B. The zooplankton of the surface waters of the Delaware Bay region. Bull. Bingham Oceanogr. Collect. 1960, 17, 5-53.

19. Cronin, L.E.; Daiber, J.D.; Hulbert, E.M. Quantitative seasonal aspects of zooplankton in the Delaware River Estuary. Chesap. Sci. 1962, 3, 63-93. [CrossRef]

20. Sandoz, M.; Rogers, R. The effect of environmental factors on hatching, moulting, and survival of zoea larvae of the blue crab Callinectes sapidus Rathbun. Ecology 1944, 25, 216-228. [CrossRef]

21. Costlow, J.D., Jr. The effect of salinity and temperature on survival and metamorphosis of megalops of the blue crab Callinectes sapidus. Helgol Wiss Meeresunters 1967, 15, 84-97. [CrossRef]

22. McConaugha, J.R.; Johnson, D.F.; Provenzano, A.J.; Maris, R.C. Seasonal distribution of larvae of Callinectes sapidus (Crustacea; Decapoda) in the waters adjacent to Chesapeake Bay. J. Crustacean Biol. 1983, 3, 582-591. [CrossRef]

23. Sulkin, S.D.; Van Heukelem, W.; Kelly, P.; Van Heukelem, L. The behavioral basis of larval recruitment in the crab Callinectes sapidus Rathbun: A laboratory investigation of ontogenetic changes in geotaxis and barokinesis. Biol. Bull. 1980, 159, 402-417. [CrossRef]

24. Provenzano, A.J.; McConaugha, J.R.; Philips, K.; Johnson, D.F.; Clark, J. Vertical distribution of first stage larvae of the blue crab, Callinectes sapidus at the mouth of Chesapeake Bay. Estuar. Coast. Shelf Sci. 1983, 16, 489-500. [CrossRef]

25. Epifanio, C.E. Transport of blue crab Callinectes sapidus larvae in the waters off Mid-Atlantic States. Bull. Mar. Sci. 1995, 57, 713-725.

26. MD DNR, Maryland Department of Natural Resources Coastal Bays Fisheries Advisory Committee. Coastal Bays Blue Crab Fisheries Management Plan; MD DNR: Annapolis, MD, USA, 2001; 44p.

27. Jesien, R.V.; Bollinger, A.; Brinker, D.F.; Casey, J.F.; Doctor, S.B.; Etgen, C.P.; Eyler, T.B.; Hall, M.R.; Hoffman, M.L.; Kilian, J.V.; et al. Diversity of Life in the Coastal Bays. In Shifting Sands: Environmental and Cultural Changes in Maryland's Coastal Bays; Dennison, W.C., Thomas, J.E., Cain, C.J., Carruthers, T.J.B., Hall, M.R., Jesien, R.V., Wazniak, C.E., Wilson, D.E., Eds.; IAN Press; University of Maryland Center for Environmental Science (UMCES): Cambridge, MD, USA, 2009; pp. 293-344.

28. Boynton, W.R.; Hagy, J.D.; Murray, L.; Stokes, C.; Kemp, W.M. A comparative analysis of eutrophication patterns in a temperate coastal lagoon. Estuaries 1996, 19, 408-421. [CrossRef]

29. Wazniak, C.; Wells, D.; Hall, M. The Maryland coastal bays ecosystem. In Maryland Coastal Bays Ecosystem Health Assessment; Wazniak, C., Hall, M., Eds.; DNR-12-1202-0009; Maryland Department of Natural Resources: Annapolis, MD, USA, 2004.

30. Glibert, P.M.; Hinkle, D.C.; Sturgis, B.; Jesien, R.V. Eutrophication of a Maryland/Virginia Coastal Lagoon: A tipping point, ecosystem changes, and potential Causes. Estuaries Coasts 2014, 37, S128-S146. [CrossRef] 
31. Quaglietta, C.E. Predation by Mnemiopsis leidyi on Hard Clam Larvae and Other Natural Zooplankton in Great South Bay, NY. Master's Thesis, State University of New York, Stony Brook, NY, USA, 1987.

32. McNamara, M.E.; Lonsdale, D.J.; Cerrato, R.M. Shifting abundance of the ctenophore Mnemiopsis leidyi and its implications for larval bivalve mortality. Mar. Biol. 2010, 157, 401-412. [CrossRef]

33. Kang, X.; Xia, M.; Pitula, J.S.; Chigbu, P. Dynamics of water and salt exchange in Maryland Coastal Bays. Estuar. Coast. Shelf Sci. 2017, 189, 1-16. [CrossRef]

34. Thomas, J.E.; Woerner, J.L.; Abele, R.W.; Blazer, D.P.; Blazer, G.P.; Cain, C.J.; Dawson, S.L.; McGinty, M.K.; Schupp, C.A.; Spaur, C.C.; et al. Isle of Wight Bay. In Shifting Sands: Environmental and Cultural Changes in Maryland's Coastal Bays; Dennison, W.C., Thomas, J.E., Cain, C.J., Carruthers, T.J.B., Hall, M.R., Jesien, R.V., Wazniak, C.E., Wilson, D.E., Eds.; IAN Press; University of Maryland Center for Environmental Science (UMCES): Cambridge, MD, USA, 2009; pp. 101-116.

35. Howson, U.A.; Buchanan, G.A.; Nickels, J.A. Zooplankton community dynamics in a western mid-Atlantic lagoonal estuary. J. Coast. Res. 2017, 78, 141-168. [CrossRef]

36. Egloff, D.A.; Fofonoff, P.W.; Onbé, T. Reproductive biology of marine cladocerans. Adv. Mar. Biol. 1997, 31, 79-168.

37. Sandifer, P.A. Morphology and Ecology of Chesapeake Bay Decapod Crustacean Larvae. Ph.D. Thesis, University of Virginia, Charlottesville, VA, USA, 1972.

38. Oseji, O.F.; Fan, C.; Chigbu, P. Composition and dynamics of phytoplankton in the coastal bays of Maryland, USA, revealed by microscopic counts and diagnostic pigments analyses. Water 2019, 11, 368. [CrossRef]

39. Ter Braak, C.J.F.; Šmilauer, P. Canoco Reference Manual and User's Guide: Software for Ordination, Version 5.0; Microcomputer Power: Ithaca, NY, USA, 2012.

40. Shannon, C.E. A mathematical theory of communication. Bell Syst. Technol. J. 1948, 27, 379-423. [CrossRef]

41. Clarke, K.R.; Gorley, R.N. PRIMER v6: User Manual/Tutorial (Plymouth Routines in Multivariate Ecological Research; PRIMER-E Limited: Plymouth, UK, 2006.

42. Oghenekaro, E.U.; Chigbu, P.; Oseji, O.F.; Tang, K.W. Seasonal factors influencing the abundance of copepods in the Maryland Coastal Bays. Estuaries and Coasts 2018, 41, 495-506. [CrossRef]

43. Burrell, V.G., Jr.; Van Engel, W.A. Predation by and distribution of a ctenophore, Mnemiopsis leidyi A. Agassiz, in the York River estuary. Estuar. Coast. Mar. Sci. 1976, 4, 235-242. [CrossRef]

44. Mills, C.E. Medusae, siphonophores and ctenophores as planktonorous predators in changing global ecosystems. ICES J. Mar. Sci. 1995, 52, 575-581. [CrossRef]

45. Purcell, J.E.; Shiganova, T.A.; Decker, M.B.; Houde, E.D. The ctenophore Mnemiopsis in native and exotic habitats: U.S. estuaries versus the Black Sea basin. Hydrobiologia 2001, 451, 145-176. [CrossRef]

46. Purcell, J.E.; Arai, M.N. Interactions of pelagic cnidarians and ctenophores with fishes: A review. Hydrobiologia 2001, 451, 24-27.

47. Purcell, J.E.; Decker, M.B. Effects of climate on relative predation by scyphomedusae and ctenophores on copepods in Chesapeake Bay during 1987-2000. Limnol. Oceanogr. 2005, 50, 376-387. [CrossRef]

48. Kremer, P. Predation by the ctenophore Mnemiopsis leidyi in Narragansett Bay, Rhode Island. Estuaries 1979, 2, 97-105. [CrossRef]

49. Turner, J.T. The annual cycle of zooplankton in a Long Island Estuary. Estuaries 1982, 5, 261-274. [CrossRef]

50. Murphy, R.F.; Secor, D.H. Fish and Blue crab assemblage structure in a U.S. mid-Atlantic Coastal lagoon complex. Estuaries Coasts 2005, 29, 1121-1131. [CrossRef]

51. Vouglitois, J.J.; Able, K.W.; Kurtz, R.J.; Tighe, K.A. Life history and population dynamics of the bay anchovy in New Jersey. Trans. Am. Fish. Soc. 1987, 116, 141-153. [CrossRef]

52. Kinch, J.C. Trophic habits of the juvenile fishes within artificial waterways: Marco Island, Florida. Contrib. Mar. Sci. 1979, 22, 77-90.

53. Vasquez, A.V. Energetics, Trophic Relationships and Chemical Composition of Bay Anchovy, Anchoa mitchilli, in Chesapeake Bay. Master's Thesis, University of Maryland, College Park, MD, USA, 1989.

54. O'Brien, M. Marine Influence on Juvenile Fish Trophic Ecology and Community Dynamics in Maryland's Northern Coastal Lagoons. Master's Thesis, Marine Estuarine Environmental Science, University of Maryland, College Park, MD, USA, 2013.

55. Mayor, E.D. Population Dynamics of Mysids and Their Role in the Trophic Ecology of Fishes in Maryland Coastal Bays. Ph.D. Thesis, University of Maryland Eastern Shore, Princess Anne, MD, USA, 2015. 
56. Starczak, V.; Pérez-Brunius, P.; Levine, H.E.; Gyory, J.; Pineda, J. The role of season and salinity in influencing barnacle distributions in two adjacent coastal mangrove lagoons. Bull. Mar. Sci. 2011, 87, 275-299. [CrossRef]

57. Sandison, E.E. The effect of salinity fluctuations on the life cycle of Balanus pallidus stutsburi Darwin in Lagos Harbour, Nigeria. J. Anim. Ecol. 1966, 35, 363-378. [CrossRef]

58. Vieira, L.; Azeiteiro, U.; Ré, P.; Pastorinho, R.; Marques, J.C.; Morgado, F. Zooplankton distribution in a temperate estuary (Mondego estuary southern arm: Western Portugal). Acta Oecol. 2003, 24, S163-S173. [CrossRef]

59. Hwang, J.S.; Kumar, R.; Hsieh, C.W.; Kuo, A.Y.; Souissi, S.; Hsu, M.H.; Wu, J.T.; Liu, W.C.; Wang, C.F.; Chen, Q.C. Patterns of zooplankton distribution along the estuarine, marine and riverine portions of Danshuei ecosystem in northern Taiwan. Zool. Stud. 2010, 49, 335-352.

60. Oseji, O.F.; Chigbu, P.; Oghenekaro, E.; Waguespack, Y.; Chen, N. Spatial and temporal patterns of phytoplankton composition and abundance in the Maryland Coastal Bays: The influence of freshwater discharge and anthropogenic activities. Estuar. Coast. Shelf Sci. 2018, 207, 119-131. [CrossRef]

61. Gunter, G.; Ballard, B.S.; Venkataramiah, A. A review of salinity problems of organisms in United States coastal areas subject to the effects of engineering works. Gulf Res. Rep. 1974, 4, 380-475. [CrossRef]

62. Santhakumari, V.; Tiwari, L.R.; Nair, V.R. Species composition, abundance and distribution of hydromedusae from Dharamtar estuarine system, adjoining Bombay harbor. Indian J. Mar. Sci. 1999, 28, 158-162.

63. Hansson, L.J.; Moeslund, O.; Kiørboe, T.; Riisgard, H.U. Clearance rates of jellyfish and their potential predation impact on zooplankton and fish larvae in a neritic ecosystem (Limfijorden, Denmark). Mar. Ecol. Prog. Ser. 2005, 304, 117-131. [CrossRef]

64. Nelson, T.C. On the occurrence and food habits of ctenophores in New Jersey inland coastal waters. Biol. Bull. 1925, 48, 92-111. [CrossRef]

65. Eversole, A.G. Species Profile: Life History and Environmental Requirements of Coastal Fishes and Invertebrates (South Atlantic)—Hard Clam; TR EL-82-4; U.S. Army Corps of Engineers: Washington, DC, USA, 1987; 33p.

(C) 2019 by the authors. Licensee MDPI, Basel, Switzerland. This article is an open access article distributed under the terms and conditions of the Creative Commons Attribution (CC BY) license (http://creativecommons.org/licenses/by/4.0/). 